\title{
Modulation of 5-Lipoxygenase in Proteotoxicity and Alzheimer's Disease
}

\author{
Elvira Valera, Richard Dargusch, Pamela A. Maher, and David Schubert \\ The Salk Institute for Biological Studies, La Jolla, California 92037-1002
}

The accumulation of intracellular $\beta$ amyloid $(\mathrm{A} \beta)$ may be one of the factors leading to neuronal cell death in Alzheimer's disease (AD). Using a pyrazole called CNB-001, which was selected for its ability to reduce intracellular A $\beta$, we show that the activation of the eIF $2 \alpha /$ ATF4 arm of the unfolded protein response is sufficient to degrade aggregated intracellular A $\beta$. CNB-001 is a potent inhibitor of 5-lipoxygenase (5-LOX), decreases 5-LOX expression, and increases proteasome activity. 5-LOX inhibition induces eIF2 $\alpha$ and PERK (protein kinase R-like extracellular signal-regulated kinase) phosphorylation, and HSP90 and ATF4 levels. When fed to AD transgenic mice, CNB-001 also increases eIF2 $\alpha$ phosphorylation and HSP90 and ATF4 levels, and limits the accumulation of soluble A $\beta$ and ubiquitinated aggregated proteins. Finally, CNB-001 maintains the expression of synapse-associated proteins and improves memory. Therefore, 5-LOX metabolism is a key element in the promotion of endoplasmic reticulum dysfunction, and its inhibition under conditions of stress is sufficient to reduce proteotoxicity both in vivo and in vitro.

\section{Introduction}

A major participant in Alzheimer's disease (AD) pathology may be the accumulation of intracellular amyloid- $\beta$ (A $\beta$; Oakley et al., 2006; LaFerla et al., 2007; Steele and Gandy, 2011). However, the molecular mechanisms leading to this form of proteotoxicity are not known, nor are the pathways that promote the clearance of intracellular amyloid understood. We have used a drug discovery approach for $\mathrm{AD}$ based in part upon the ability of compounds to remove intracellular A $\beta$ (Liu et al., 2008; Chen et al., 2011; Schubert and Maher, 2012). A library of hybrid compounds between curcumin and the neurotrophic molecule cyclohexyl bisphenol A was screened in toxicity assays that represent multiple degenerative pathways involved in aging and $\mathrm{AD}$, including intracellular amyloid toxicity. One synthetic curcumin derivative, called CNB-001, was identified that has the ability to stimulate the removal of intracellular A $\beta$ (Liu et al., 2008). Experiments were then performed using CNB-001 to gain insight into the molecular basis of intraneuronal amyloid clearance.

Several studies have shown that aberrant endoplasmic reticulum (ER) stress is associated with $\mathrm{AD}$, and that reduced $\mathrm{ER}$ function enhances A $\beta$ toxicity (Kaneko et al., 2010; Lee do et al., 2010; Lee et al., 2010; Kögel et al., 2012). In addition, the disruption of 5-lipoxygenase (5-LOX) and some phospholipases reduces $\mathrm{AD}$ pathology, and 5-LOX is elevated in AD (Qu et al., 2000; Firuzi et al., 2008; Sanchez-Mejia et al., 2008; Oliveira et al., 2010). How-

\footnotetext{
Received Nov. 2, 2012; revised May 10, 2013; accepted May 17, 2013.

Author contributions: P.A.M. and D.S. designed research; E.V., R.D., P.A.M., and D.S. performed research; D.S. analyzed data; E.V., P.A.M., and D.S. wrote the paper.

This research was supported by grants from The National Institutes of Health (Grant R01AG035055; D.S.), the Fritz

B. Burns Foundation (D.S. and P.A.M.), and the Alzheimer's Association (D.S.).

The authors declare no competing financial interests.

Correspondence should be addressed to David Schubert, 10010 North Torrey Pines Road, La Jolla, CA $92037-1002$. E-mail: schubert@salk.edu.

DOI:10.1523/JNEUROSCI.5183-12.2013

Copyright $\odot 2013$ the authors $\quad 0270-6474 / 13 / 3310512-14 \$ 15.00 / 0$
}

ever, no mechanistic link between the two has been identified. It is shown here that CNB-001 activates the neuroprotective eIF2 $\alpha /$ ATF4 arm of the unfolded protein response (UPR), leading to the clearance of intracellular $\mathrm{A} \beta$ aggregates, and that 5-LOX inhibition by CNB-001 accounts for this activity. In an AD mouse model, CNB-001 also induces eIF $2 \alpha$ phosphorylation and ATF4 expression, and reduces soluble $\mathrm{A} \beta_{1-42}$ and ubiquitinated insoluble proteins in the hippocampus.

\section{Materials and Methods}

Intracellular amyloid toxicity. The growth and induction of intracellular amyloid toxicity in MC65 cells was performed exactly as described previously (Maezawa et al., 2006; Liu et al., 2008). PERK ${ }^{-1-}$ mouse embryonic fibroblast (MEFs) were a gift from Antonis Koromilas (McGill University, Montreal, Quebec, Canada). Primary E18 cortical neurons were used $7 \mathrm{~d}$ after plating (Liu et al., 2008). For nuclear extraction and ATF4 measurements, MEFs were grown in $60 \mathrm{~mm}$ dishes for $24 \mathrm{~h}$ and the nuclei were harvested as described previously (Lewerenz and Maher, 2009).

huAPPswe/PS1 1 E9 transgenic mice. The APP/PS1 transgenic mice (line 85) have been well characterized (Jankowsky et al., 2007). At 3 months of age, male transgenic mice and their wild-type littermates (8-10 per group) were fed a diet with and without CNB-001 (500 ppm). Mouse body weights and food consumption were measured weekly, and there were no significant differences between the groups. The mice were tested for behavior and killed at 9 months.

Animal behavior. The Y-maze assay in Figure $11 B$ was performed as described previously (Chen et al., 2011), and the acute toxicity assay was performed by PsycoGenics, as described in the figure legend.

$A \beta$ ELISA. Soluble and RIPA-insoluble hippocampal fractions were prepared and analyzed for $A \beta$ as described previously (Chen et al., 2011).

Proteasome assay. To assay the effects of the different treatments on proteasome activity, cells from the same density cultures as used for the cell death assays were treated with varying concentrations of the proteasome inhibitors for the indicated time periods. The cells were then scraped into assay buffer (50 mM HEPES, pH 7.8, $10 \mathrm{~mm} \mathrm{NaCl}, 1.5 \mathrm{~mm}$ $\mathrm{MgCl}_{2}, 1 \mathrm{~mm}$ EDTA, 1 mм EGTA, $250 \mathrm{~mm}$ sucrose, and $5 \mathrm{~mm}$ DTT), 
A

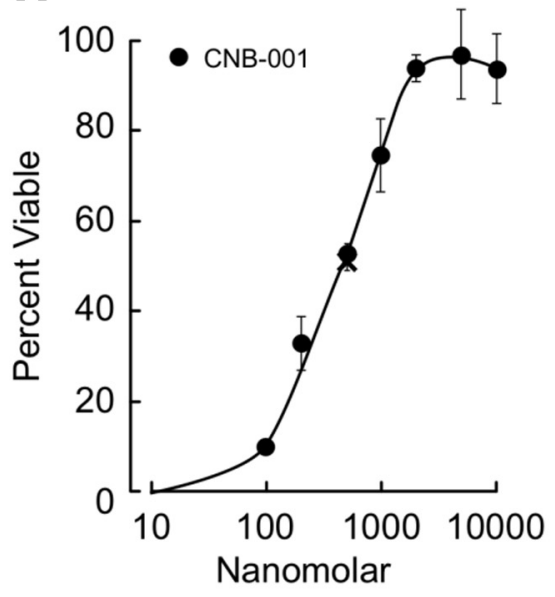

B

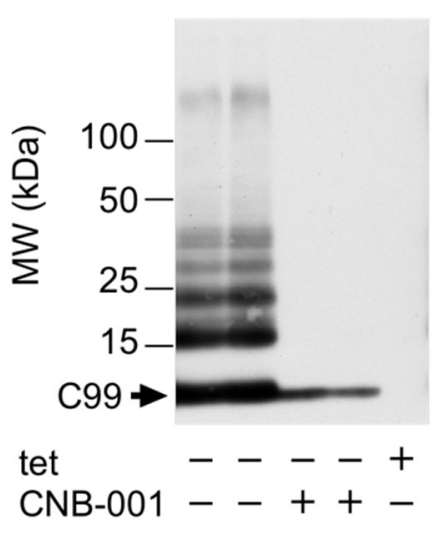

C

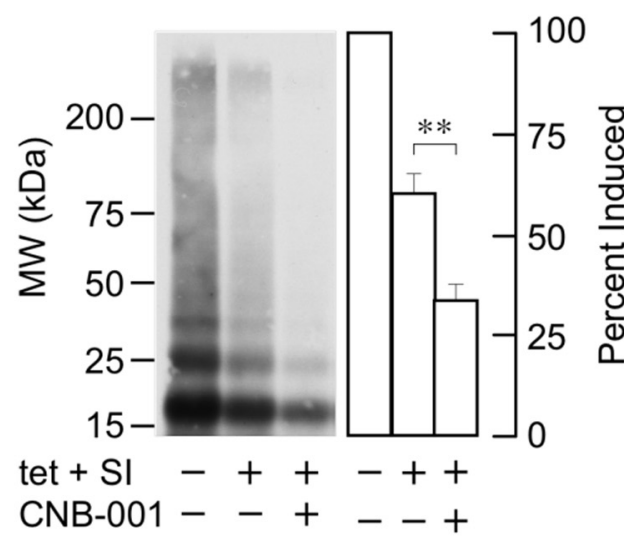

D

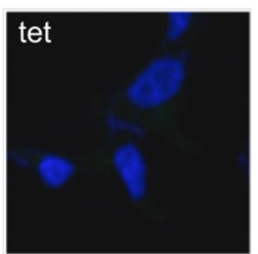

-tet

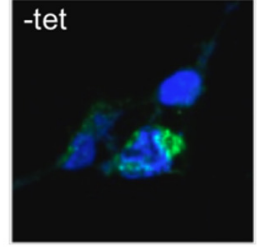

-tet +CNB-001
$\mathbf{E}$

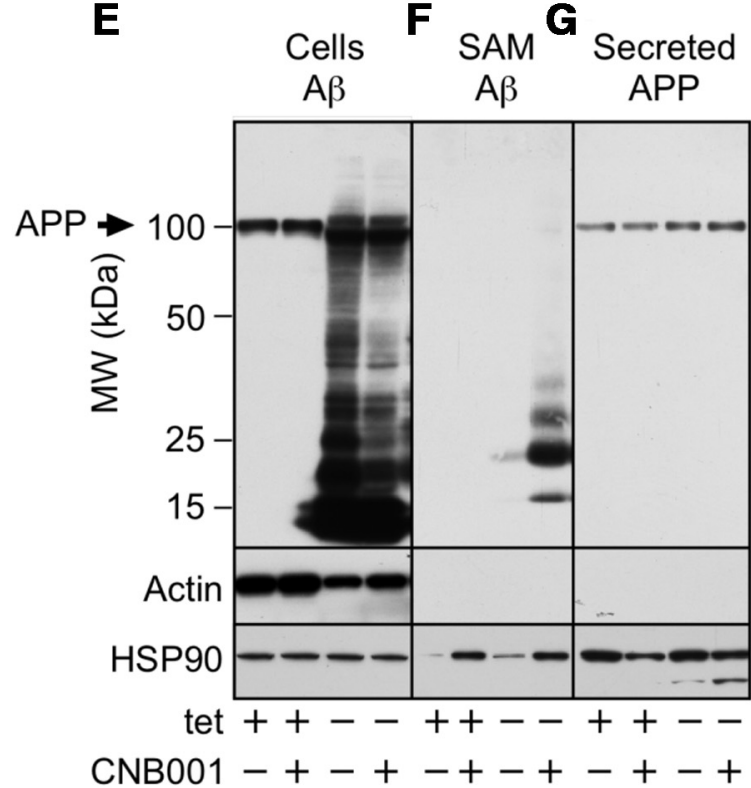

H
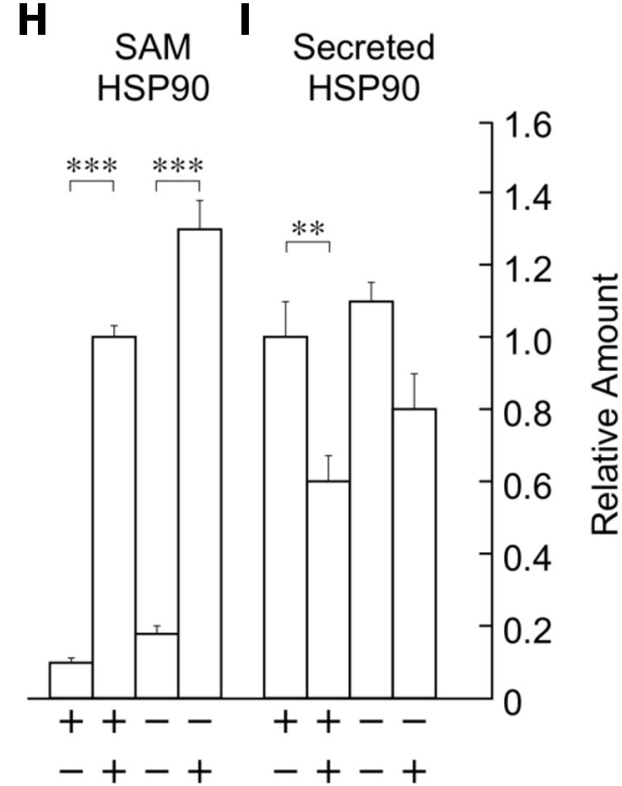

Figure 1. CNB-001 is neuroprotective against intracellular A $\beta$ toxicity. $A, M C 65$ cells were induced to make the C-terminal fragment of APP by the removal of tetracycline, followed by the addition of increasing amounts of CNB-001. Cell death was determined 4 d later by the MTT assay and confirmed visually. The data are plotted as the percentage viable relative to controls of uninduced cells, \pm SEM, $n=3 . \boldsymbol{B}$, Intracellular A $\beta$ in MC65 cells was assayed at $1 \mathrm{~d}$ following tetracycline removal in the presence $(+)$ or absence $(-)$ of $1 \mu \mathrm{M}$ CNB-001. A $\beta$ aggregates and C99 ( $\sim 13 \mathrm{kDa})$ were detected with the 6 E10 antibody. C, Cells were induced for $1 \mathrm{~d}$ to make $(99$, followed by the addition of tet and $\gamma$-secretase inhibitor 10 (SI; $5 \mu \mathrm{m}$; Calbiochem) in the presence or absence of $1 \mu \mathrm{m}$ CNB-001. One day later, the cells were harvested by the addition of sample buffer and immunoblotted for $A \beta$. Data are presented as the percentage of $A \beta$ expressed in the induced cells without tet or SI. D, MC65 cells were plated on coverslips and incubated with or without tet plus or minus CNB-001 for $2 \mathrm{~d}$. Amyloid aggregates were visualized using the $6 \mathrm{E} 10$ antibody by confocal microscopy. E-I, CNB-001 induces the deposition of A $\beta$ and HSP90 in the SAM. MC65 cells were either induced ( - tet) or uninduced ( + tet) for $24 \mathrm{~h}$. The cells were then dissociated and replated on new dishes followed by the addition of a $\gamma$-secretase inhibitor and tet to all cultures. One micromolar CNB-001 was added where indicated (+CNB-001). After another $24 \mathrm{~h}$, the cultures were separated into cells, culture medium (secreted), and SAM. The three fractions were then immunoblotted for A $\beta$ and APP (antibody 6E10), HSP90, or actin. E, Cells, anti-A $\beta$. F, SAM, anti-A $\beta$. G, Secreted, anti-A $\beta$. $\boldsymbol{H}, \boldsymbol{I}$, Quantitation of HSP90 in the SAM $(\boldsymbol{H})$ and secreted fractions $(\boldsymbol{I}) .{ }^{* *} p<0.01 ;{ }^{* * *} p<0.001, n=3-4$. Throughout the text, $n$ is the number of experiments performed to generate the statistics.

sonicated, and centrifuged at $16,000 \times g$ for $10 \mathrm{~min}$ at $4^{\circ} \mathrm{C}$. The supernatants were assayed for proteasome activity in the same buffer supplemented with $2 \mathrm{~mm}$ ATP using the chymotrypsin activity substrate Suc-LLVY-AMC (7-amino-4-methylcoumarin; Biomol), the trypsin activity substrate Z-ARR-AMC (Calbiochem), or the caspase-like activity substrate Z-LLE-AMC (Calbiochem) all at $100 \mu \mathrm{M}$ in a final volume of $250 \mu$. The mixture was incubated at $37^{\circ} \mathrm{C}$ for $60 \mathrm{~min}$, and then the released fluorogenic AMC was measured at $360 \mathrm{~nm}$ excitation and 460 $\mathrm{nm}$ emission using a fluorometric plate reader. Relative fluorescence units were normalized to protein values determined using the Bradford protein assay kit (Pierce).

SDS-PAGE and immunoblotting. All immunoblotting was done on cultured cells or RIPA-soluble hippocampal homogenates, and the protein amount was quantified exactly as described previously (Chen et al.,
2011). For aggregated proteins, the entire gel was scanned. The primary antibodies are listed below.

Primary antibodies. The following primary antibodies were used: ProBDNF (monoclonal, $32 \mathrm{kDa}$; BD Biosciences); 5-LOX (polyclonal, 78 kDa; StressMarq Biosciences; beta amyloid (monoclonal; Wako); Homer 1 (polyclonal, $40 \mathrm{kDa}$; Sigma); anti-actin 1:40,000 (polyclonal, $45 \mathrm{kDa}$; Enzo Life Sciences); clusterin (goat polyclonal, 35-40 kDa; Santa Cruz Biotechnology); synapsin-1, 1:10,000 (monoclonal, $80 \mathrm{kDa}$; Cayman Chemicals); phospho S603 synapsin 1 (polyclonal, $80 \mathrm{kDa}$; Invitrogen); protein kinase R-like extracellular signal-regulated kinase (PERK; polyclonal, 150,000 kDa; Sigma); phospho-T980 PERK (polyclonal, 150,000 kDa; Cell Signaling Technology); ubiquitin (monoclonal; Bioscience Research Reagents); heat shock protein 90 (HSP90; polyclonal, 90 kDa; Cell Signaling Technology); eIF2 $\alpha$ (polyclonal, 38 kDa; Cell Signaling Tech- 
A

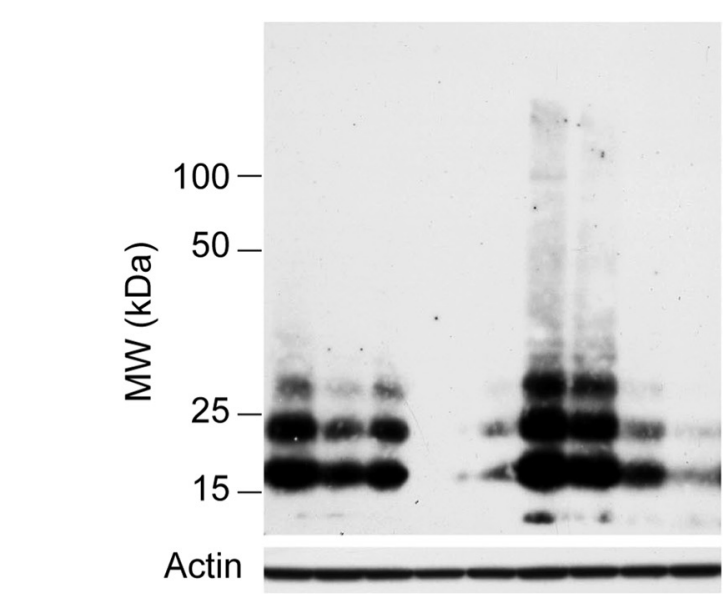

tet

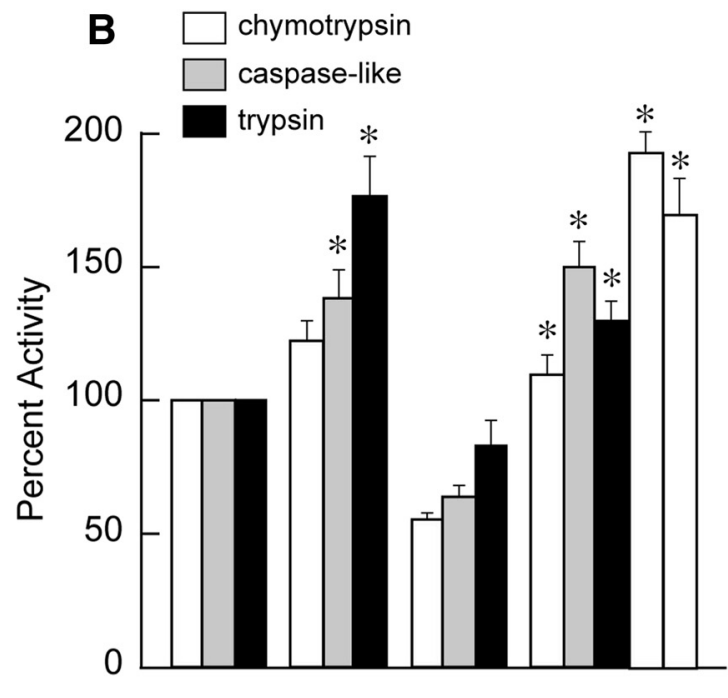

tet

MK

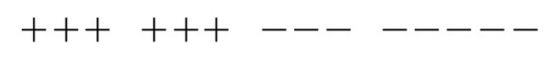

$$
\begin{array}{ll}
\text { chloroquine } & --+--+++- \text { BW }-----------+- \\
\text { lactacystin } & ----+ \text { CNB-001 }--++++---+++-- \\
\text { CNB-001 } & ---+--+++
\end{array}
$$$$
\text { CNB-001 - - + + }+--+++--
$$
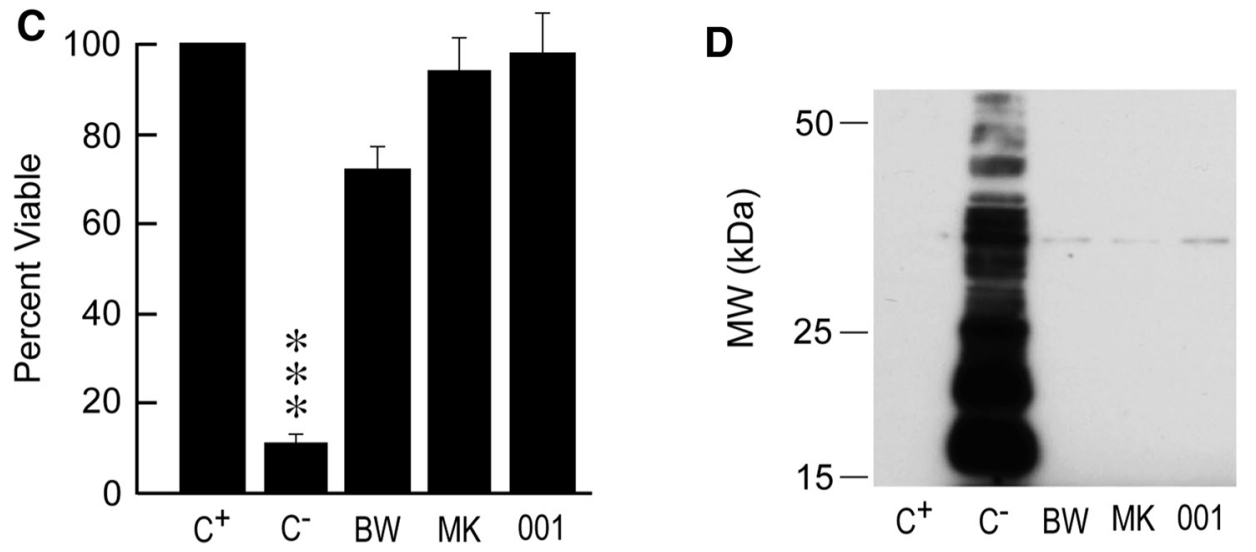

Figure 2. CNB-001 stimulates $A \beta$ clearance through both the proteasome and lysosome. $A, M C 65$ were induced to make $C 99$ for $24 \mathrm{~h}$, followed by the indicated additions of tet, $\gamma$-secretase inhibitor $10(5 \mu \mathrm{M})$, chloroquine $(50 \mu \mathrm{M})$, lactacystin $(1 \mu \mathrm{M})$, or CNB-001 $(1 \mu \mathrm{M})$. Two days later, the cells were immunoblotted for A $\beta$ or actin. $B$, MC65 cells were treated for $48 \mathrm{~h}$ in either the presence or absence of tet and the indicated compounds, and the three proteasome activities were measured. BW, BW B70C $(0.5 \mu \mathrm{M}) ; 001$, CNB-001 (1 $\mu \mathrm{M})$; MK, MK886 (2 $\mu \mathrm{M}), n=4 . \mathrm{C}, \mathrm{MC} 65$ cells were either uninduced ( $C^{+}$only) or induced ( $C^{-}$and all others) to make $A \beta$ in the presence of BW $(0.5 \mu \mathrm{m})$, MK $(2 \mu \mathrm{M})$, or $001(1 \mu \mathrm{M})$, and cell viability was determined $4 \mathrm{~d}$ later. $\boldsymbol{D}$, Western blots of cells treated as in $C$ with anti-A $\beta 48 \mathrm{~h}$ following the removal of tet. ${ }^{*} p<0.05 ;{ }^{* * *} p<0.001, n=4$.

nology); phospho-eIF2 $\alpha$ (polyclonal; Cell Signaling Technology); and ATF4 (polyclonal, $55 \mathrm{kDa}$; Santa Cruz Biotechnology).

Immunofluorescence of MC65 cells. Immunofluorescence labeling and confocal microscopy for $\mathrm{A} \beta$-immunoreactive aggregates were performed according to published protocols (Maezawa et al., 2004).

Transfection of MC65 cells. MC65 cells were plated at a density of $5 \times$ $10^{5}$ cells/well in $35 \mathrm{~mm}$ culture dishes and grown for $24 \mathrm{~h}$. Cells were transfected with $0.5 \mu \mathrm{g}$ of expression plasmid for GADD34, washed twice with PBS, and incubated for $48 \mathrm{~h}$ in OptiMEM with or without tetracycline (tet) and CNB-001, $0.5 \mu \mathrm{M}$. A $\beta$ aggregates were measured by Western blot using the antibody $6 \mathrm{E} 10$.

$m R N A$ assays. Total RNA was extracted using the RNeasy kit (Qiagen). One microgram of total RNA was used for reverse transcription reaction, and mRNA was converted to cDNA using oligo dT primers and Superscript II reverse transcriptase (Invitrogen). For quantitative PCR (qPCR) analysis, $1 \mu \mathrm{l}$ of total cDNA was diluted in $6 \mu \mathrm{l}$ of $\mathrm{H}_{2} \mathrm{O}$, and $3 \mu \mathrm{l}$ of this dilution was used in each reaction. $q P C R$ procedures. Primers for $\mathrm{qPCR}$ were designed using Primer 3 software to yield a 75-150 bp product, $20 \mathrm{bp}$ long and a melting temperature of $60^{\circ} \mathrm{C}$. PCRs were prepared in Microamp optical 96well reaction plates (Applied Biosystems). Three microliters of a 1:6 dilution of total cDNA was mixed with $5 \mu$ l of SYBR green PCR master mix $2 \times$ (Roche) and $1 \mu \mathrm{M}$ each primer pair in a total volume of $10 \mu$ l. Reactions were run in an ABI Prism 7900 Sequence Detector (Applied Biosystems), and results were analyzed with SDS2.3 software (Applied Biosystems) for Ct calculations. Calculations of $\Delta \Delta$ Ct values were performed following specifications of the manufacturer. All assays were performed at least three times and were normalized to $\beta$-actin or GAPDH in the same samples.

Data analysis. Statistical analysis of qPCR data was performed using GraphPad Prism 5 software. One-way ANOVA and Bonferroni post-test were used to compare multiple datasets. For Western blots, protein levels were normalized to actin levels. ANOVA assays with the Tukey post hoc test were used to determine differences between means for Western blot and qPCR analysis. Two-way ANOVAs with repeated measures were 

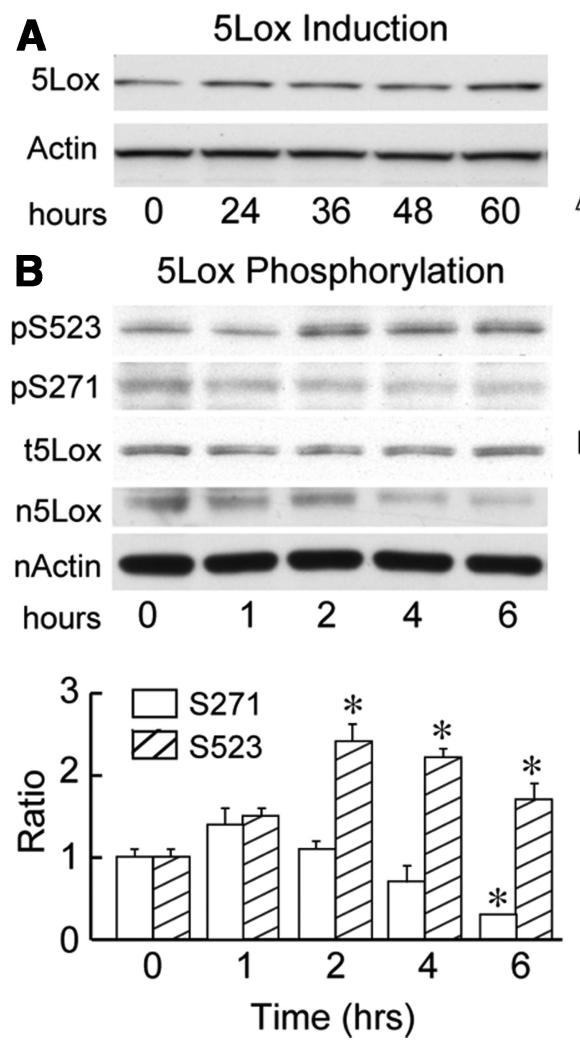

CNB-001 prevented the accumulation of $\mathrm{A} \beta$ in cytoplasmic inclusions (Maezawa et al., 2006). However, the site of C99 cleavage within the cell to $\mathrm{A} \beta$ is not known. It was then asked, what is the mechanism of $\mathrm{A} \beta$ polymer clearance?

Following the initiation of cellular stress caused by misfolded or aggregated proteins, cells mount a multifaceted stress response, including attempts to secrete the protein or degrade it via activation of the ubiquitin-proteasome pathway, direct lysosomal degradation, autophagy, or a combination of these mechanisms. The mechanism by which $\mathrm{A} \beta$ is reduced by CNB-001 was initially explored by examining its presence in the extracellular compartments following drug treatment for $24 \mathrm{~h}$. These compartments include soluble (secreted) proteins and extracellular insoluble substrate attached material (SAM). SAM is composed of proteins such as fibronectin, collagen, and proteoglycans that are attached to the culture dish, and can be regarded as a surrogate for the extracellular matrix that surrounds all cells.

SAM is experimentally defined as the material left on the culture dish after cells are removed by EGTA (Schubert, 1977). To determine whether CNB-001 causes the release of $A \beta$ into the extracellular space, MC65 cells were induced to accumulate $\mathrm{A} \beta$ for $24 \mathrm{~h}$, dissociated, and replated on new tissue culture dishes in the presence of tet and a $\gamma$-secretase inhibitor plus or minus CNB-001 for an additional $24 \mathrm{~h}$. Figure $1 E$ shows that intracellular used with behavioral data, and Tukey or Dunnett post hoc tests were used for multiple comparisons. Significance was rejected at the 0.05 level.

\section{Results}

CNB-001 increases the clearance of intracellular $\mathrm{A} \boldsymbol{\beta}$

To determine how CNB-001 alters the metabolism of intracellular A $\beta$, MC65 cells were used that conditionally express the C99 fragment of the amyloid precursor protein (APP) under the control of a tet promoter (Sopher et al., 1994). Upon the removal of tet, MC65 cells express C99, which is cleaved to A $\beta$ by $\gamma$-secretase. $\mathrm{A} \beta$ polymers accumulate within the cells, leading to cell death within $4 \mathrm{~d}$ (Sopher et al., 1994; Maezawa et al., 2006). The addition of $\gamma$-secretase inhibitors blocks cell death but allows the accumulation of the nontoxic C99 protein (Maezawa et al., 2006; Hong et al., 2007). Figure $1, A$ and $B$, shows that when MC65 cells were induced to generate $\mathrm{A} \beta$ in the presence of $\mathrm{CNB}-001 \mathrm{~A} \beta$ accumulation is inhibited and the cells were protected from cell death with an $\mathrm{IC}_{50}$ of $\sim 500$ nM. Cells do not accumulate monomeric A $\beta$, and C99 does not polymerize (Maezawa et al., 2004, 2006; Hong et al., 2007).

To determine whether CNB-001 has the ability to remove preformed intracellular $\mathrm{A} \beta$ aggregates, cells were induced to make $\mathrm{A} \beta$ for $24 \mathrm{~h}$, followed by the addition of tet and a $\gamma$-secretase inhibitor to block further C99 synthesis and A $\beta$ production. CNB-001 was then added for an additional $24 \mathrm{~h}$. Figure $1 C$ shows that $\mathrm{CNB}-001$ enhanced the removal of preformed aggregates. Figure $1 D$ shows by immunocytochemistry that
C99 and $A \beta$ aggregates were reduced by CNB-001. Furthermore, $\mathrm{A} \beta$ was only found in the SAM following exposure to CNB-001 (Fig. $1 F)$. A $\beta$ was not detected secreted in the culture medium (Fig. $1 G$ ); APP was only in the medium, and CNB-001 did not reduce APP levels inside or outside of cells (Fig. $1 \mathrm{E}, \mathrm{G}$ ). It follows that $\mathrm{CNB}-001$ can stimulate the deposition of $\mathrm{A} \beta$ in the extracellular space associated with matrix proteins.

HSPs are induced in response to stress and to maintain aggregation-prone proteins in a properly folded state to prevent their accumulation. In some cases, HSPs are secreted (Song and Luo, 2010). HSP90 has the ability to directly bind $A \beta$ and inhibit the early stages of amyloid aggregation (Evans et al., 2006), and HSP90 and $\mathrm{A} \beta$ are cosecreted under conditions of stress (Goldsbury et al., 2008). We therefore examined the levels of HSP90 in the intracellular, SAM, and the soluble secreted protein compartments of MC65 cells with or without $\mathrm{CNB}-001$ treatment. Figure $1, E, F$, and $H$, shows that CNB-001 greatly enhanced the deposition of HSP90 in SAM but had no effect on intracellular HSP90. In contrast to the results with SAM, CNB-001 decreased the accumulation of HSP90 in the soluble medium fraction (Fig. 1G,I). These data are consistent with the observation that $\mathrm{CNB}-001$ enhanced the deposition of $\mathrm{A} \beta$ from cells into the extracellular space, perhaps in conjunction with HSP90. However, quantifying the amount of $A \beta$ in the SAM indicated that only $5-10 \%$ of the protein depleted from cells by CNB-001 was in 
this fraction. We therefore asked, what is the mechanistic basis for the removal of the majority of the aggregated $\mathrm{A} \beta$ ?

\section{Intracellular $\mathrm{A} \boldsymbol{\beta}$ is degraded via} lysosomal and proteasomal pathways Besides secretion, there are multiple alternatives for the removal of intracellular aggregated proteins, including direct proteolysis through the proteasome and various pathways leading to the lysosome, including autophagy. Autophagy is enhanced in the AD brain, perhaps as a protective mechanism (Nixon, 2007), and the activation of autophagy in fly brains removes aggregated protein and extends lifespan (Simonsen et al., 2008). However, no evidence for the induction of autophagy by CNB-001 could be found as defined by electron microscopy, changes in p62 or LC3, or inhibition by rapamycin (data not shown). Therefore, the effect of CNB-001 on protein degradation directly via proteasomes or lysosomes was examined.

MC65 cells were induced to synthesize C99 for $24 \mathrm{~h}$ followed by the addition of tet and the $\gamma$-secretase inhibitor to block further $\mathrm{C} 99$ and $\mathrm{A} \beta$ production. Different combinations of CNB-001, the proteasome inhibitor lactacystin, or the lysosome inhibitor chloroquine were then added, and the accumulation of aggregated $\mathrm{A} \beta$ was determined 48 h later. Figure $2 A$ shows that CNB-001 effectively stimulated the removal of $\mathrm{A} \beta$ from cells, as did the proteasome inhibitor lactacys-

tin. Chloroquine blocked the clearance of $\mathrm{A} \beta$ by lactacystin and reduced the clearance by $\mathrm{CNB}-001$, and the combination of chloroquine and lactacystin completely inhibited $\mathrm{A} \beta$ removal by CNB-001. Cell viability after $4 \mathrm{~d}$ could not be determined because of the toxicity of lactacystin. Figure $2 B$ shows that CNB-001 increases all three proteasomal protease activities. Therefore, $\mathrm{CNB}-001$ stimulates $\mathrm{A} \beta$ degradation through both the proteasome and the lysosome, and the experimental inhibition of the proteasome pathway redirects clearance through lysosomes. Similar dual-pathway mechanisms of protein turnover have been reported (Komatsu et al., 2006), as have examples where the inhibition of the proteasome redirects proteins to lysosomes (Zhu et al., 2010).

\section{The inhibition of 5-LOX leads to $\mathrm{A} \boldsymbol{\beta}$ degradation}

Because of the structural similarity of CNB-001 to several LOX inhibitors, the ability of CNB-001 to inhibit the three human LOX isoforms was examined. CNB-001 inhibits 5-LOX with an $\mathrm{IC}_{50}$ of $\sim 70 \mathrm{nM}$ (performed by Ricerca Biosciences; data not shown). There is no inhibition of human 12-LOX or 15-LOX below $5 \mu \mathrm{m}$. It was then asked whether the selective 5-LOX inhibitor BW B70C and the 5-LOX activating protein (FLAP) inhibitor MK886 could mimic the effects of CNB-001 on $\mathrm{A} \beta$ clearance and proteasome activity and inhibit cell death. Figure $2 B$ shows that BW B70C and MK886 activated the proteasome, and both 5-LOX inhibitors blocked the death of induced MC65 cells (Fig. 2C). Figure $2 D$ shows that they also prevented $A \beta$ accumulation. Therefore, the inhibition of 5-LOX by three molecularly distinct molecules and two mechanisms is sufficient for the removal of intracellular A $\beta$ and the maintenance of MC65 viability.

The activity and metabolic stability of 5-LOX is largely determined by its subcellular distribution, with the stable active state associated with the nucleus. Localization is determined by phosphorylation. The phosphorylation of S523 leads to exit from the nucleus, while the phosphorylation of S271 leads to nuclear localization and an increase in activity (Luo et al., 2005). Figure $3 A$ shows that the accumulation of A $\beta$ within MC65 cells leads to increased 5-LOX expression, and Figure $3 B$ shows that CNB-001 increased the phosphorylation of S573 and decreased S271 phosphorylation, and there was a time-dependent loss of 5-LOX from the nucleus in the presence of CNB-001.

\section{CNB-001 activates one arm of the UPR}

The accumulation of proteins within cells can trigger the UPR, leading to increased protein degradation. Three response pathways participate in the UPR. These are mediated by PERK, ATF6, and inositol-requiring enzyme $1 \alpha(\operatorname{IRE} 1 \alpha)$. HSP90 is a surrogate marker for the UPR (Kunte et al., 2012), and CNB-001 strongly induces the synthesis of this protein (Fig. $1 F$ ). To determine whether the UPR contributes to the effect of CNB-001 on cell survival, several components of each arm were assayed using both 


\section{LOX KO Glia}

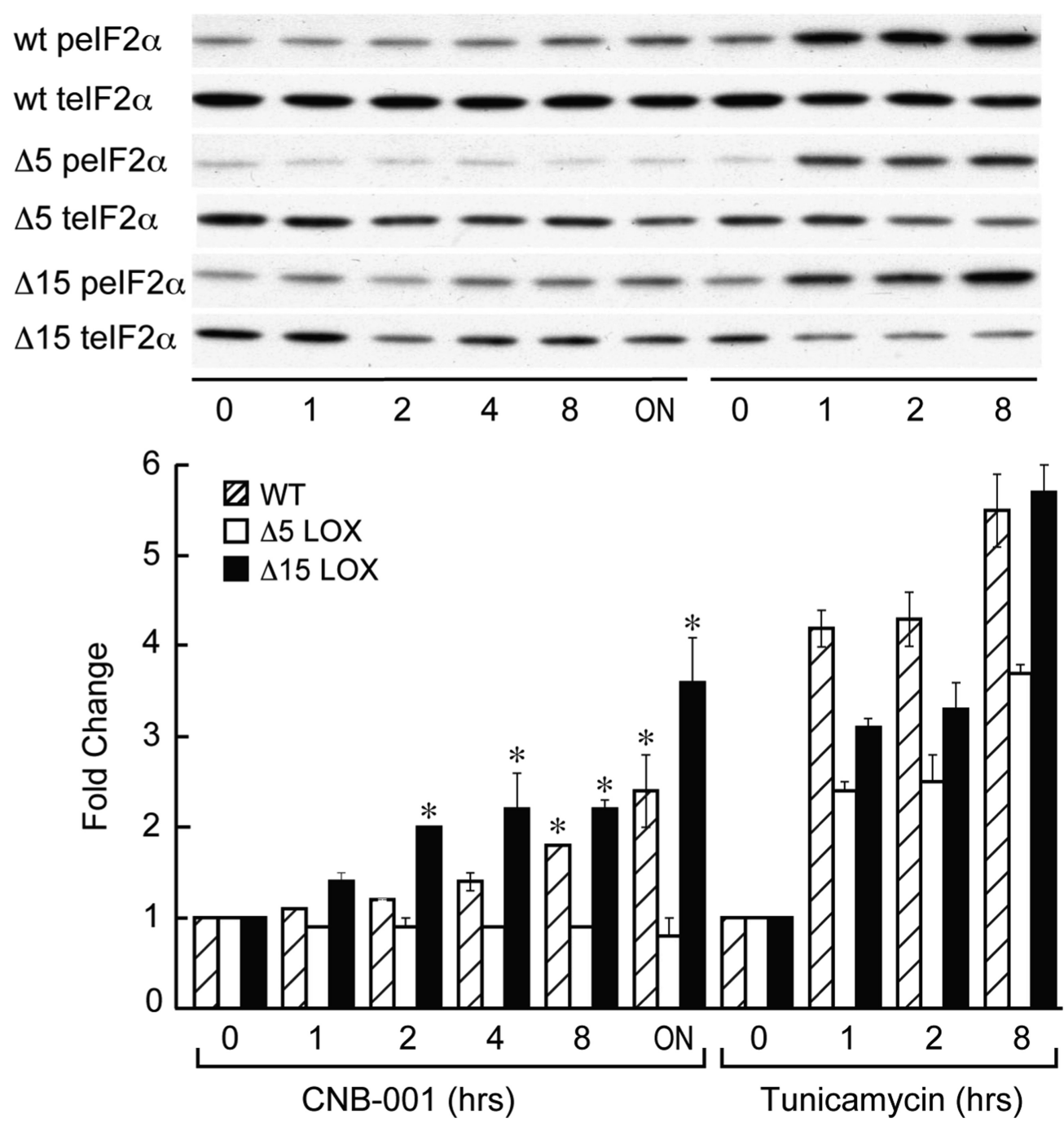

Figure 5. CNB-001 does not elevate elF2 $\alpha$ phosphorylation in 5-LOX knock-out mouse astrocytes. Astrocytes were prepared from newborn wild-type, 5-LOX, or 12/15 L0X knock-0ut mice (Jackson Laboratories) using standard procedures. Confluent cultures were treated with $1 \mu \mathrm{M}$ CNB-001 or tunicamycin, and elF2 $\alpha$ phosphorylation was followed as a function of time. 0N, 0vernight; pelF $2 \alpha$, phospho-elF $2 \alpha$; telF $2 \alpha$, total elF $2 \alpha$. ${ }^{*} p<0.01$ relative to control without drugs. $n=3$.

Western blotting and quantitative RT-PCR (qRT-PCR). The following shows that CNB-001 primarily activates one arm of the UPR, that this pathway is sufficient to remove aggregated $A \beta$ and promote cell survival, and that it can also be activated by the inhibition of 5-LOX.

Since we have shown that the phosphorylation of eIF $2 \alpha$ leads to neuroprotection from oxidative stress-induced programmed cell death (Tan et al., 2001b) and eIF $2 \alpha$ is involved in learning and memory (Trinh et al., 2012), the role of eIF $2 \alpha$ phosphorylation in CNB-001-mediated protection was examined first. To compare the effect of CNB-001 to that of a bona fide UPR inducer, cells were also treated with tunicamycin. Figure $4 A$ shows that in uninduced cells ( + tet) both CNB-001 and tunicamycin caused a transient increase in eIF2 $\alpha$ phosphorylation, while in induced cells CNB-001 caused a more sustained phosphorylation of eIF2 $\alpha$ ( - tet; Fig. $4 B$ ). When MC65 cells were grown with or without tet for $24 \mathrm{~h}$, the basal level of eIF $2 \alpha$ phosphorylation was decreased by $75 \%$ in induced cells (Fig. $4 C$ ). When added after $24 \mathrm{~h}, \mathrm{CNB}-001$ dose-dependently increased eIF $2 \alpha$ phosphorylation in induced cells while CNB-001 decreased eIF $2 \alpha$ phosphor- ylation in uninduced (+tet) cells at this longer time point (Fig. $3 C$ ). Therefore, the effect of CNB-001 on eIF $2 \alpha$ phosphorylation is dependent upon whether or not the cells have accumulated a toxic peptide.

It was then asked whether the inhibition of 5-LOX is also sufficient to cause the phosphorylation of eIF $2 \alpha$. Figure $4 D$ shows there was a dose-dependent increase in eIF $2 \alpha$ phosphorylation by the FLAP inhibitor MK886, and Figure $4 E$ shows the time course of this increase. Similar results were obtained with BW B70C, which, like CNB-001, is a direct 5 -LOX enzyme inhibitor (data not shown). Figure 5 shows that CNB-001 does not induce eIF $2 \alpha$ phosphorylation in astrocytes from 5-LOX knock-out mice, while it does in wildtype and 12/15-LOX knock-out astrocytes. Finally, overnight treatment with CNB-001 lowered the expression of 5-LOX in MC65 cells (Fig. 6B).

The phosphorylation of eIF $2 \alpha$ increases the translation of the transcription factor ATF4 to activate the expression of several UPR target genes. ATF4 is also involved in the reduction of oxidative stress and the maintenance of glutathione levels (Lewerenz 
A
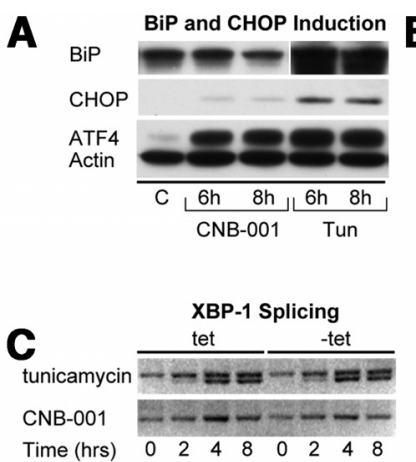

D
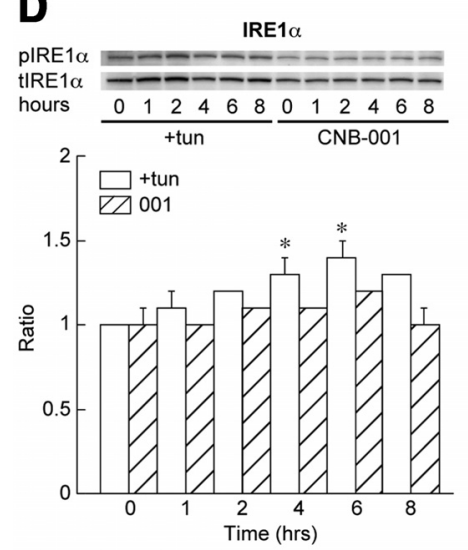
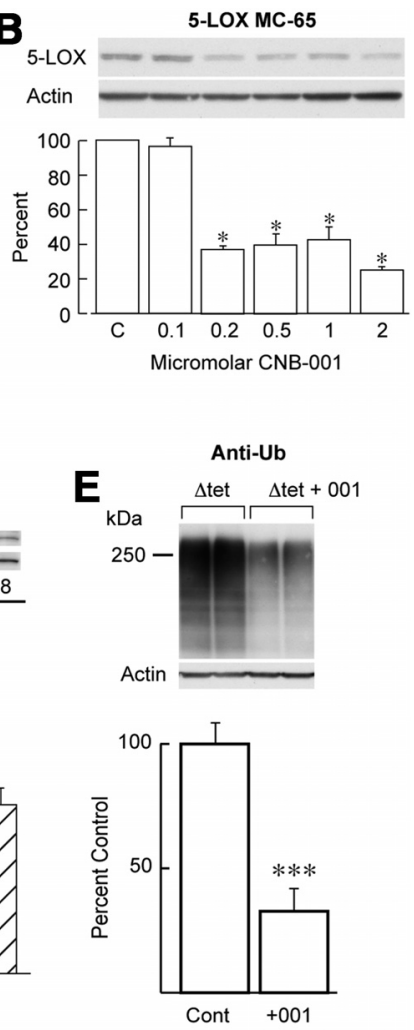

Figure 6. A, MC65 cells were exposed to $500 \mathrm{~nm}$ CNB- 001 or $5 \mu \mathrm{g} / \mathrm{ml}$ tunicamycin (Tun) and Western blotted for actin, BiP, CHOP, and ATF4 at 6 and 8 h. B, 5-LOX was assayed in uninduced MC65 cells following a $20 \mathrm{~h}$ exposure to the indicated amounts of CNB-001 $(n=4)$. C, The splicing of XBP-1 was assayed by RT-PCR at the indicated times. Only tunicamycin increased splicing. $\boldsymbol{D}$, The phosphorylation of IRE1 $\alpha$ was monitored following exposure to $500 \mathrm{~nm}$ CNB001 or $5 \mu \mathrm{g} / \mathrm{ml}$ tunicamycin. $E$, MC65 cells were induced for $2 \mathrm{~d}$, and the RIPA-insoluble fraction blotted with anti-ubiquitin or actin. ${ }^{*} p<0.01 ;{ }^{* * *} p<0.001 . n=4-10$.

and Maher, 2009). Figures $4 F$ and $6 A$ show that CNB-001 increased the expression of ATF4 in a time-dependent manner in both MC65 cells and primary cortical neurons. In contrast, the downstream, pro-death protein $\mathrm{CHOP}$ is only induced weakly by CNB-001 relative to tunicamycin (Fig. 6A).

To determine whether CNB-001 also modulates the other arms of the UPR, IRE1 $\alpha$ activation was measured using an antibody against S724 of IRE1 $\alpha$. While tunicamycin increased IRE1 $\alpha$ phosphorylation, CNB-001 did not (Fig. 5D). The activation of IRE1 $\alpha$ stimulates the deletion of a $26 \mathrm{nt}$ intron from XBP-1 mRNA. Tunicamycin induced this splicing event, but CNB-001 did not (Fig. 6C). The third arm of the UPR is mediated by ATF6. Tunicamycin increased the expression of ATF6 in the nucleus, but CNB-001 did not as defined by Western blotting (data not shown). BiP is a recognized target of ATF6, and it was not increased by CNB-001 (Fig. 6A). Therefore, while eIF $2 \alpha$ phosphorylation and ATF4 expression are upregulated by CNB-001, the ATF6 and IRE $1 \alpha$ arms of the UPR are poorly activated.

To verify the Western blotting data, we examined the CNB001-dependent expression of several ATF4-mediated gene transcripts by qPCR (Fig. 7). There was increased mRNA expression of $x$ CT/SLC7A11, ATF3, ASNS, and GADD34/PPP1R15A. We also observed a transient increase in CHOP/DDIT3, HERP/ HERPUD1, and ATF4 (Fig. 8) mRNA, but there was only a limited increase in the expression of the CHOP protein (Fig. 6A). Finally, as predicted by the Western blot results, there were no significant changes in the mRNA levels of genes classically upregulated by the ATF6 or IRE1 $\alpha$ arms of the UPR (Fig. 8).

Four kinases stimulate eIF2 $\alpha$ phosphorylation. In the UPR, the phosphorylation of eIF $2 \alpha$ is mediated by PERK. To determine whether PERK plays a role in the induction of eIF $2 \alpha$ phosphorylation and ATF4 expression by CNB-001, fibroblasts from PERK knock-out mice were used. CNB-001 was added to the cultures and the expression of ATF4 was monitored. Figure 3C shows that the deletion of PERK led to dramatically decreased ATF4 expression relative to wild-type fibroblasts following exposure to CNB-001. PERK itself is activated by phosphorylation, and Figure 3D shows that CNB-001 caused the phosphorylation of PERK in a time-dependent manner. Together, these data demonstrate that the upregulation of the neuroprotective eIF $2 \alpha /$ ATF4 pathway by CNB-001 is likely to be initiated by PERK.

\section{eIF2 $\alpha$ phosphorylation is sufficient for $A \beta$ clearance}

Three experiments were performed to determine whether the phosphorylation of eIF $2 \alpha$ alone is sufficient to clear intracellular $\mathrm{A} \beta$. In the first experiment, the dephosphorylation of $\operatorname{IF} 2 \alpha$ was induced and the effects on $\mathrm{A} \beta$ clearance and cell survival examined. GADD34 recruits the serine/threonine protein phosphatase PP1 to eIF $2 \alpha$ and stimulates its dephosphorylation. When overexpressed in MC65 cells, GADD34 decreased eIF2 $\alpha$ phosphorylation by $\sim 80 \%$ (Fig. $9 A$ ) and promoted the death of transfected cells within 2 versus $4 \mathrm{~d}$ for control cells (Fig. $9 B$ ). Overexpression of GADD34 also caused increased intracellular $\mathrm{A} \beta$ accumulation in induced MC65 cells (Fig. 9A). Salubrinal inhibits the dephosphorylation of the $\alpha$-subunit of eIF $2 \alpha$ (Lewerenz and Maher, 2009). Therefore, if the phosphorylation of eIF $2 \alpha$ is sufficient to clear intracellular $\mathrm{A} \beta$ and protect cells from intracellular $\mathrm{A} \beta$ toxicity, salubrinal should promote both activities. Figure $9, C$ and $D$, shows that this was indeed the case. The third experiment was to ask whether another compound that induces eIF $\alpha$ phosphorylation but does not inhibit 5-LOX is able to promote $\mathrm{A} \beta$ clearance. J147 is a potent neuroprotective compound (Chen et al., 2011), but a very poor 5-LOX inhibitor, with an $\mathrm{IC}_{50}$ over $4 \mu \mathrm{M}$ (data not shown). Fifty nanomolar J147 caused the phosphorylation of eIF $2 \alpha$, cleared intracellular $\mathrm{A} \beta$, and prevented cell death (Fig. 9E,F). Together, these data suggest that the phosphorylation of eIF $2 \alpha$ is sufficient to remove intracellular A $\beta$ and promote cell viability.

\section{Apomorphine activates eIF2 $\alpha$ and removes intracellular A $\beta$}

We have shown that apomorphine is very neuroprotective against oxidative stress-induced nerve cell death in the absence of intracellular $\mathrm{A} \beta$, and it does so by the activation of the dopamine D4 receptor (Ishige et al., 2001). Apomorphine also prevents the accumulation of intracellular $\mathrm{A} \beta$ in $\mathrm{AD}$ transgenic mice (Himeno et al., 2011). To determine whether apomorphine stimulates eIF2 $\alpha$ phosphorylation and clears intracellular A $\beta$ from MC65 cells, MC65 cells were treated with apomorphine, and eIF $2 \alpha$ phosphorylation followed as a function of time (Fig. 10A) and after $24 \mathrm{~h}$ (Fig. 10B). Apomorphine increased the phosphorylation of eIF $2 \alpha$ and also PERK (Fig. 3B). Figure 10, $C$ and $D$, shows that apomorphine also cleared intracellular $\mathrm{A} \beta$ aggregates and prevented cell death. The possibility that CNB-001 directly activated the $\mathrm{D} 4$ receptor in addition to inhibiting 5 -LOX was ruled out because the $\mathrm{D} 4$ antagonist U1011958 did not block the effect of CNB-001 on A $\beta$ clearance and $10 \mu \mathrm{M}$ CNB-001 did not inhibit direct agonist binding to the dopamine receptors D4.2, D4.4, or D4.7 (performed by Ricerca Biosciences). 

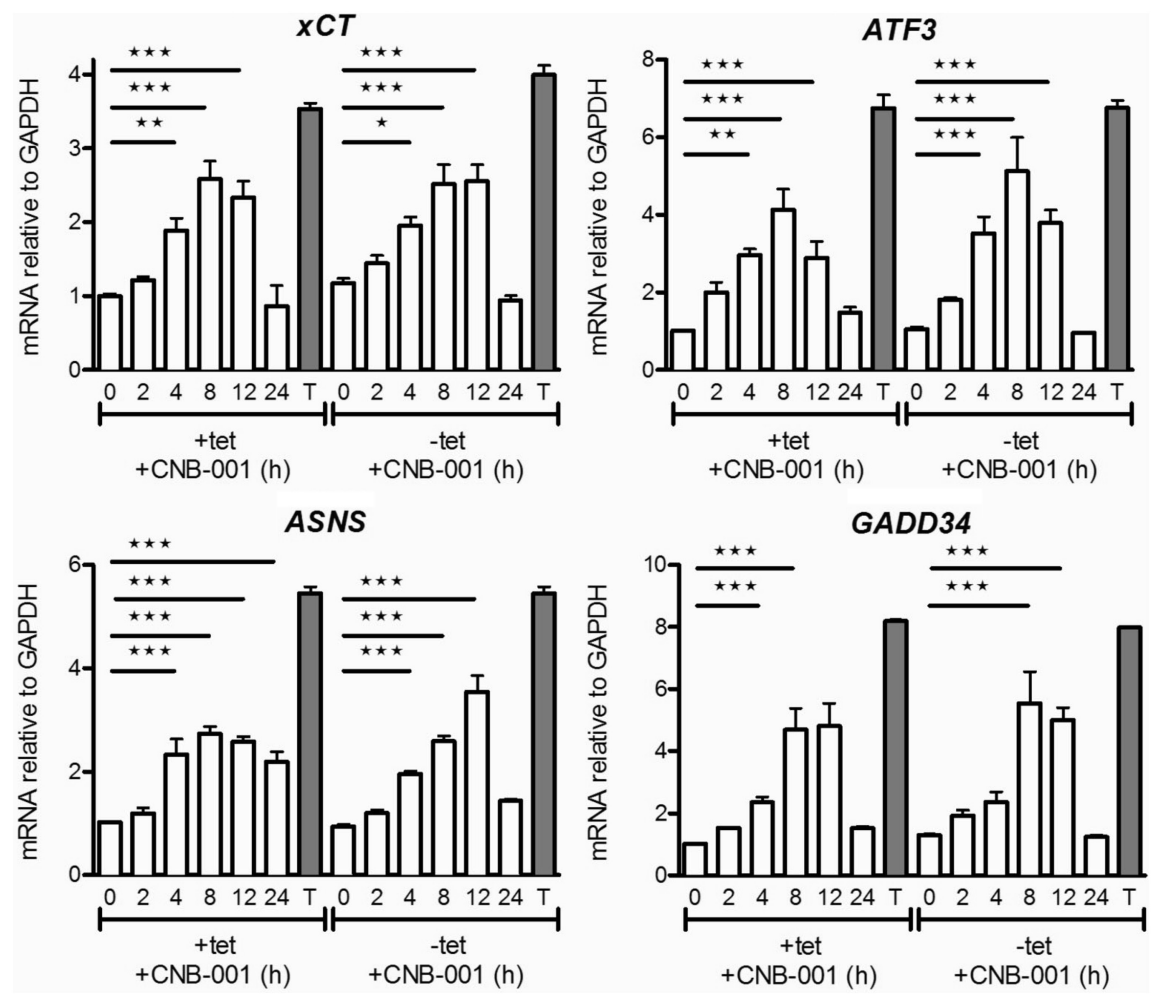

Figure 7. CNB-001 activates the elF $\alpha$ arm of the UPR. MC65 cells were either induced ( + tet) or uninduced ( - tet) for $24 \mathrm{~h}$. At this time, $1 \mu \mathrm{M}$ CNB-001 was added, and mRNA was harvested at 0,2, 4, 8, 12, and $24 \mathrm{~h}$ followed by qRT-PCR for the expression of the indicated genes. T indicates incubation with tunicamycin $5 \mu \mathrm{g} / \mathrm{ml}$ for $8 \mathrm{~h}$ as a positive control. Analysis was done by ANOVA. ${ }^{*} p<0.05$; ${ }^{* *} p<0.01$; ${ }^{* * *} p<0.001$.

\section{Efficacy of CNB-001 in AD transgenic mice}

Since CNB-001 stimulates LTP and rodent memory (Maher et al., 2010), CNB-001 was initially assayed in mice in an acute $\mathrm{A} \beta$ toxicity assay using a contextual memory-conditioning paradigm. CNB-001 completely reversed the memory loss caused by $\mathrm{A} \beta_{1-42}$ (Fig. 11A). While this memory-enhancing effect is likely to be too rapid to be due to relief from intracellular amyloid accumulation, it may be due to the rapid activation of the BDNF signaling pathways by CNB-001 (Liu et al., 2008; Figure 11E,F).

We next determined the efficacy of CNB-001 in preventing behavioral impairment in a transgenic mouse strain expressing mutated human APP and PS-1, the APPswe/PS1 $\Delta$ E9 line (line 85; Jankowsky et al., 2005). This strain develops amyloid plaques at $\sim 6$ months of age and behavioral deficits by 9 months of age. $\mathrm{AD}$ mice and nontransgenic littermates were placed on a diet containing CNB-001 at $500 \mathrm{ppm}(\sim 25 \mathrm{mg} / \mathrm{kg} / \mathrm{d})$ starting at 3 months of age, and control $\mathrm{AD}$ and nontransgenic mice received the identical chow without CNB-001. At 9 months of age, the mice were tested in a behavioral paradigm to assay memory and then killed for biochemical analysis. The Y-maze was used to assess working memory as the spontaneous tendency to alternate free choices in entering the three arms of the maze. The groups of animals did not differ in the overall number of arm entries, suggesting that activity levels were not altered by CNB-001 treatment. When control mice were given a choice of entering the arms in the Y-maze, they tended to alternate their choices spontaneously. Nine-month-old AD transgenic mice, however, had less of a tendency than control mice to alternate the arms on successive choices (Fig. 11B), which is characteristic of animals with damage to the hippocampus. In contrast, in $\mathrm{AD}$ mice fed CNB-001 the behavior approached that of the nontransgenic controls. Because CNB-001 increases the UPR in cultured cells, it was asked whether the same occurs in mice.

In cultured cells, CNB-001 increases the phosphorylation of eIF2 $\alpha$, increases ATF4 and HSP90 expression, and promotes the clearance of aggregated proteins, all markers for UPR activation. Figure 11, $C$ and $H$, shows that HSP90 and ATF4 were elevated by CNB-001 in the hippocampal extracts of $\mathrm{AD}$ mice relative to untreated $\mathrm{AD}$ mice, and Figure $12 \mathrm{~A}$ shows that CNB-001 dramatically increased eIF $2 \alpha$ phosphorylation in both control and $\mathrm{AD}$ mice. Our antisera were unable to detect any PERK phosphorylation in the lysates due to low expression levels of the protein. 5-LOX was reduced by CNB-001 in both wild-type and $\mathrm{AD}$ mice (Fig. 12F).

There are a number of biochemical parameters that covary with memory improvement in drug-treated, cognitively deficient rodents. Among these is synapsin-1, an actin-binding protein that is involved in synaptic vesicle recycling and is activated by phosphorylation by CaMKII at serine 603. Since CNB-001 activates CaMKII (Maher et al., 2010), we assayed the phosphorylation of synapsin-1 in the hippocampi of the animals. Figure $11 D$ shows that CNB-001 increased synapsin-1 phosphorylation. Figure $11 E$ shows that CNB-001 increased pro$\mathrm{BDNF}$ levels in $\mathrm{AD}$ mice. BDNF directly regulates the expression of several genes involved in synaptic spine formation. Homer 1 is an actin binding protein that is induced by BDNF (Sato et al., 2001). Homer 1 was increased in AD brain and was further increased by CNB-001 (Fig. $11 F$ ). Finally, clusterin is a secretory protein that is implicated in $\mathrm{AD}$ pathology, including a role in the proapoptotic aspect of the ER stress response (Kögel et al., 2012). It was elevated in line $85 \mathrm{AD}$ transgenic mice and reduced by CNB-001 (Fig. 11G).

\section{CNB-001 reduces soluble $\mathrm{A} \boldsymbol{\beta}_{1-42}$ and ubiquitinated protein aggregates}

The therapeutic target for $\mathrm{AD}$ drugs has historically been the removal of amyloid plaques, but more recently it has been argued that lower-molecular-weight soluble polymers made up primarily of $\mathrm{A} \beta_{1-42}$ are responsible for much of the $\mathrm{AD}$ pathology (Krafft and Klein, 2010). Indeed, in the line $85 \mathrm{AD}$ mice that we used, soluble $\mathrm{A} \beta$, perhaps of intraneuronal origin, is the primary contributor to cognitive decline, not insoluble $\mathrm{A} \beta$ (Zhang et al., 2011). There were abundant amyloid plaques in the line $85 \mathrm{AD}$ transgenic animals at 9 months, but there were no significant differences between drug-treated and control animals. There was also no change in $\mathrm{A} \beta$ levels in the RIPA-insoluble fraction of $\mathrm{AD}$ mice treated with $\mathrm{CNB}-001$, relative to control AD mice (Fig. $12 B)$, nor were RIPA-soluble $A \beta_{1-40}$ levels significantly lowered (Fig. 12C). However, CNB-001 caused a 50\% reduction in the levels of soluble $\mathrm{A} \beta_{1-42}$ (Fig. 12D).

Since the accumulation of aggregated ubiquitinated proteins in the brain is associated with normal aging and their removal extends lifespan in flies (Simonsen et al., 2008), it was asked 
CHOP/DDIT3
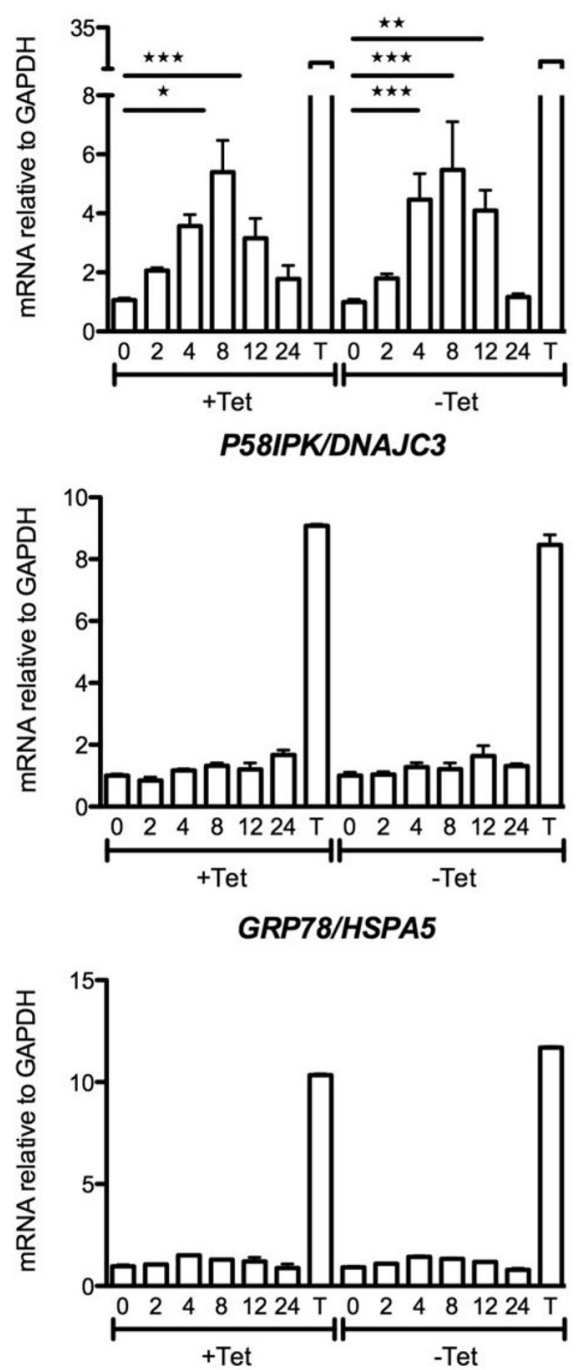

HERP/HERPUD1
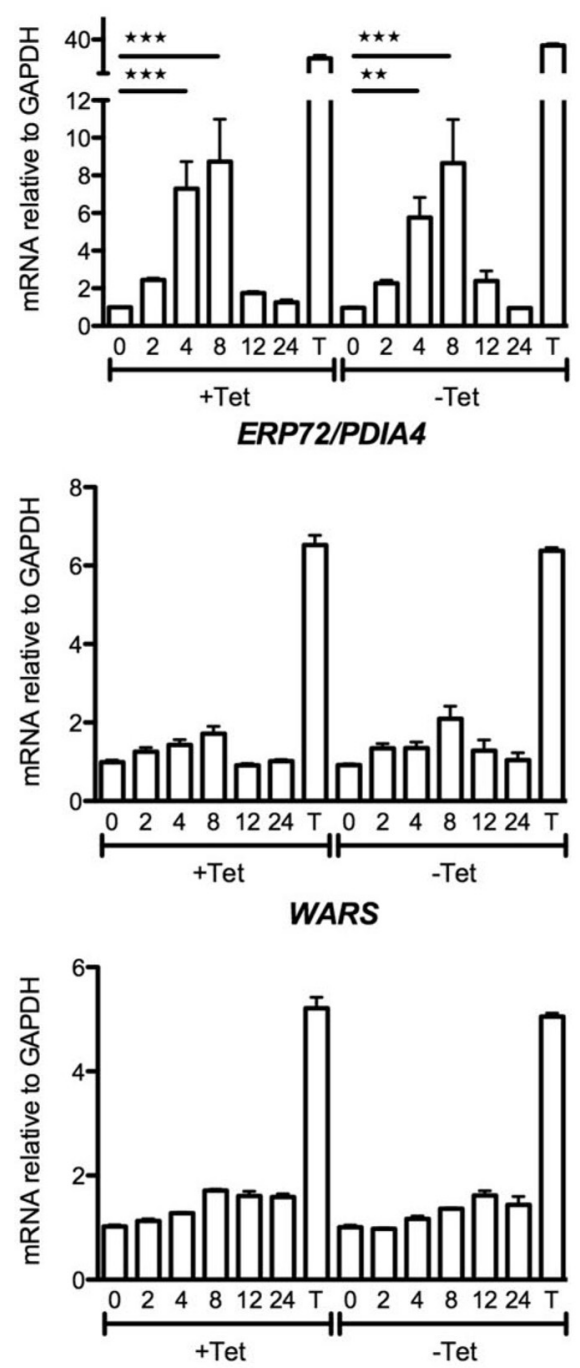

ATF4
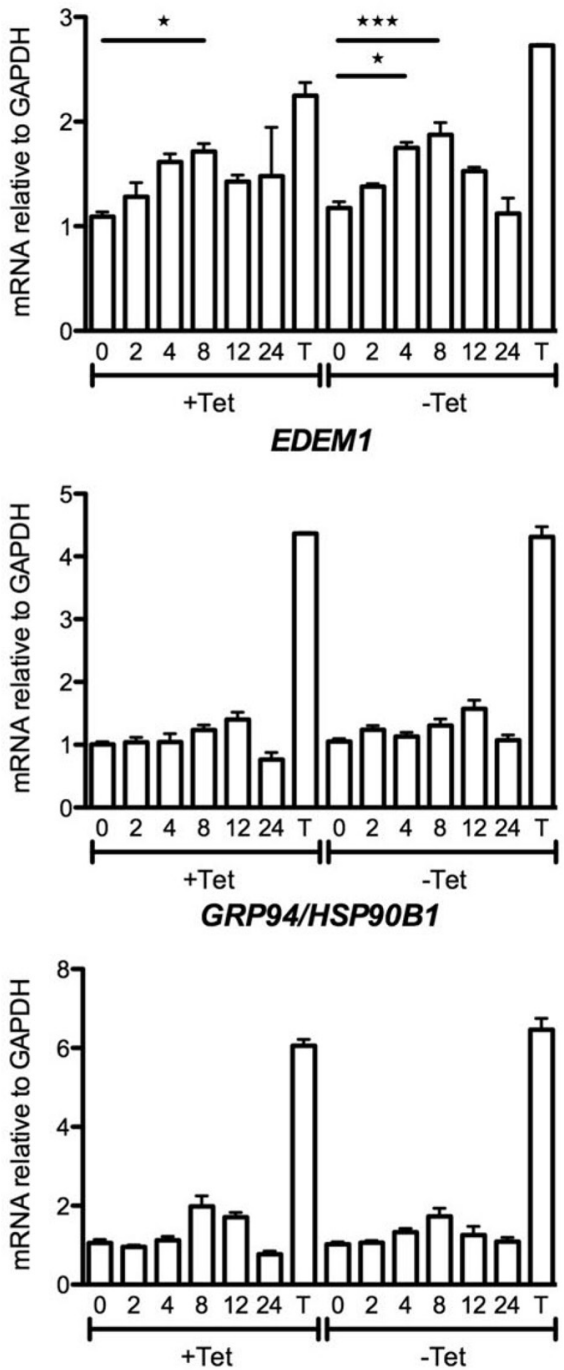

Figure 8. CNB-001 does not activate the ATF6 or the IRE1 $\alpha$ arms of the UPR. MC65 cells were either induced ( + tet) or uninduced ( - tet) for $24 \mathrm{~h}$. At this time, $1 \mu \mathrm{m}$ CNB-001 was added, and mRNA was harvested at $0,2,4,8,12$, and $24 \mathrm{~h}$ followed by $q \mathrm{PCR}$ for the expression of the indicated genes. T indicates incubation with tunicamycin $5 \mu \mathrm{g} / \mathrm{ml}$ for $8 \mathrm{~h}$ as positive control. Genes in the top row are associated with the elF2 $\alpha /$ ATF4 arm, and the remaining six with the ATF6 and IRE1 $\alpha$ arms of the UPR. Analysis was done by AN0VA. ${ }^{*} p<0.05$; ${ }^{* *} p<0.01$; ${ }^{* * *} p<0.001$.

whether the removal of protein aggregates by $\mathrm{CNB}-001$ is unique to $A \beta$ or extends to other aggregates. Figure $12 E$ shows that in 9-month-old wild-type mice that were fed CNB-001 at $500 \mathrm{ppm}$ in their food for 6 months there was a $50 \%$ reduction of ubiquitinated protein aggregates in their hippocampi. There was also a reduction of ubiquitinated proteins in many $\mathrm{AD}$ mice, but this was not statistically significant due to variation between individual animals. When MC65 cells were treated with CNB-001 for $2 \mathrm{~d}$, there was also a reduction of RIPA-insoluble ubiquitinated proteins (Fig. 6E). Together, these data support the argument that the eIF $2 \alpha$ arm of the UPR is activated by CNB- 001 in AD mice in a manner similar to the response in cultured cells (Fig. 13).

\section{Discussion}

The above data show that the stimulation of eIF $2 \alpha$ phosphorylation is sufficient to reduce the amount of intracellular $\mathrm{A} \beta$ polymers through a combination of proteasomal and lysosomal degradation, and that the inhibition of 5-LOX can induce this response. The accumulation of intracellular $\mathrm{A} \beta$ is likely to be a major cause of nerve cell death in $\mathrm{AD}$. This conclusion is sup- ported by a number of observations: (1) in humans, intracellular $\mathrm{A} \beta$ accumulation precedes plaques; (2) nerve cell death occurs in mutant PS1 transgenic mice that have extensive intraneuronal $\mathrm{A} \beta$, but no plaques (Chui et al., 1999); (3) there is intraneuronal $\mathrm{A} \beta$ accumulation well before extracellular amyloid in several different AD models (Wirths et al., 2001; Billings et al., 2005; Oakley et al., 2006; Tampellini et al., 2010); (4) the reduction in intracellular $\mathrm{A} \beta$ also reduces soluble $\mathrm{A} \beta$ in vivo (Oddo et al., 2006); and (5) the removal of intracellular $\mathrm{A} \beta$ by apomorphine in 3XFAD mice before there are plaques improves memory and reduces $\mathrm{AD}$ pathology (Himeno et al., 2011). Our results show that CNB-001 and apomorphine both reduce intracellular $A \beta$ in cultured cells and stimulate eIF $2 \alpha$ phosphorylation, suggesting that they share a common mechanism for $\mathrm{A} \beta$ clearance.

$\mathrm{A} \beta$ degradation occurs in MC65 cells treated with CNB-001 in the absence of ultrastructural or biochemical evidence for autophagy. A combination of proteasomal and lysosomal degradation of $\mathrm{A} \beta$ without the involvement of autophagy has been reported (Chakrabortee et al., 2012). The data presented here 
A

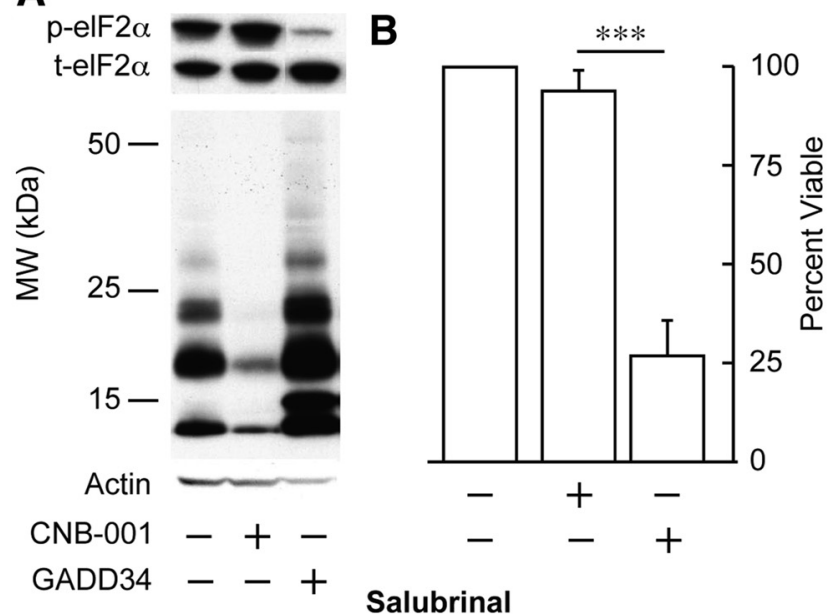

D
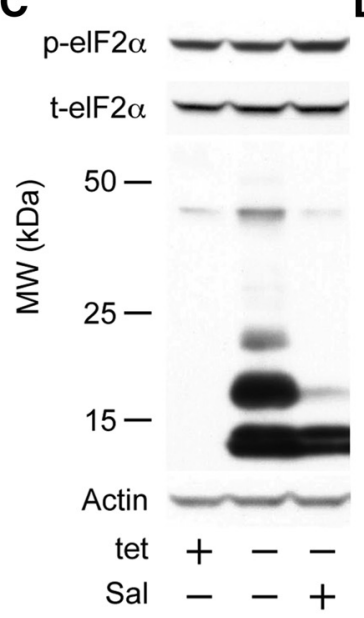

E

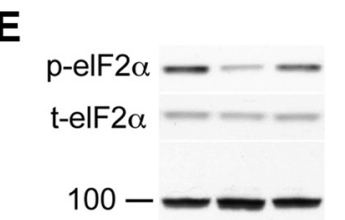

\section{$\mathbf{F}$}

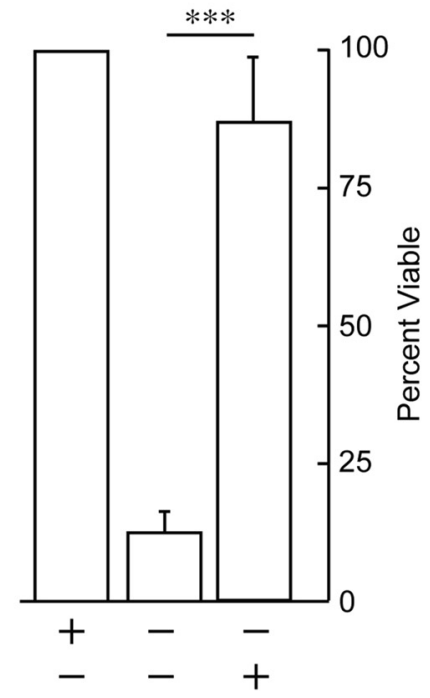

Figure 9. elF2 $\alpha$ phosphorylation, intracellular $A \beta$, and viability. MC65 cells were exposed to the following conditions, and elF $2 \alpha$ phosphorylation, intracellular $A \beta$, and cell viability were determined. $A$, Cells were transfected with an expression plasmid for GADD34 or empty plasmid. After $24 \mathrm{~h}$, cells were induced to make $A \beta$ and $1 \mu \mathrm{m}$ CNB-001 was added. elF $2 \alpha$ phosphorylation was determined $24 \mathrm{~h}$ later (top). Intracellular $A \beta$ levels were determined after $2 \mathrm{~d}(A$, bottom), and cell viability was determined after $3 \mathrm{~d}(\boldsymbol{B})$. $\boldsymbol{C}, \boldsymbol{D}$, Induced MC65 cells were exposed to $20 \mu \mathrm{m}$ salubrinal and intracellular $\mathrm{A} \beta$, elF $2 \alpha$ phosphorylation was determined after $2 \mathrm{~d}(\boldsymbol{C})$, and cell viability was determined on day 4 (D).E, Induced MC65 cells were exposed to $50 \mathrm{~nm} \mathrm{J147}$ for $2 \mathrm{~d}$, and elF2 $\alpha$ phosphorylation and intracellular $\mathrm{A} \beta$ levels were determined. $\boldsymbol{F}$, Cell viability was assayed at day $4 .{ }^{* * *} p<0.001 . n=3-4$.

A

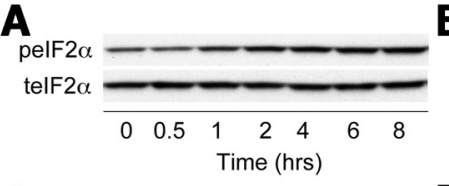

pelF2 $2 \alpha-\infty$
telF $2 \alpha$
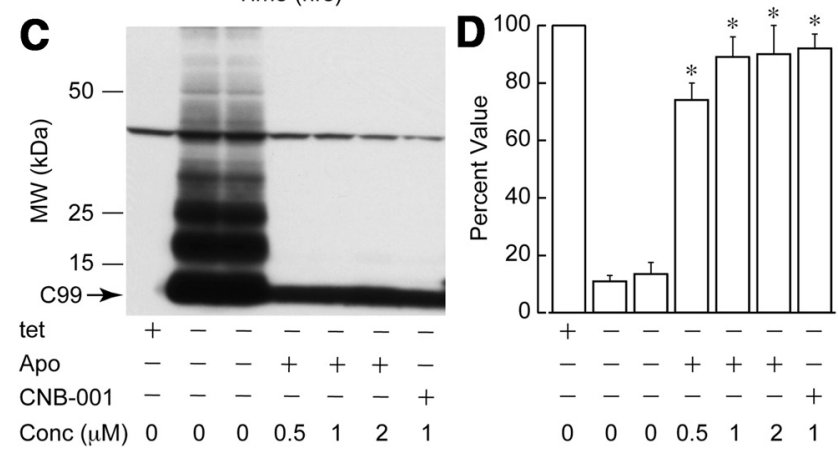

Figure 10. Apomorphine (Apo) induced elF $2 \alpha$ phosphorylation, clears $A \beta$ polymers, and blocks cell death. $A$, Induced MC65 cells were exposed to $1 \mu$ m apomorphine for the indicated amounts of time and were immunoblotted for phospho- and total elF $2 \alpha . \boldsymbol{B}$, MC65 cells were grown without tet for $24 \mathrm{~h}$ followed by the addition of the indicated amounts of apomorphine for an additional $24 \mathrm{~h}$, and were immunoblotted as in A. C, MC65 cells were incubated with (+) or without ( - ) tet for $24 \mathrm{~h}$ in the presence of the indicated amounts of apomorphine or CNB001 , and were immunoblotted with anti-A $\beta$ (6E10). D, Cell viability was determined $4 \mathrm{~d}$ later under the same conditions as in $C .{ }^{*} p<0.05 . n=3$.

suggest that proteasomal and lysosomal degradation pathways associated with the UPR are directly responsible for the removal of $\mathrm{A} \beta$ by CNB-001, a result supported in vivo by the strong phosphorylation of eIF $2 \alpha$ by CNB-001-elevated ATF4 and HSP90, and the reduction of soluble $\mathrm{A} \beta_{1-42}$ and protein aggregates. Additionally, CNB-001 induces the deposition of a small fraction of the intracellular amyloid load as $\mathrm{A} \beta$ polymers in the extracellular matrix compartment. The ability of a compound to enhance $\mathrm{A} \beta$ secretion is desirable, as the impaired ability to secrete $A \beta$ and reduce intraneuronal $\mathrm{A} \beta$ may promote $\mathrm{AD}$ pathogenesis (Tampellini et al., 2011).

Neuronal 5-LOX expression increases with age and is highly elevated in $\mathrm{AD}$ brains, and $\mathrm{AD}$ transgenic mice lacking 5-LOX have reduced levels of A $\beta$ (Qu et al., 2000; Firuzi et al., 2008). Mice deficient in phospholipase A2- or D2-derived arachidonic acid, the major 5-LOX substrate, also have reduced ADassociated memory deficits (Sanchez-Mejia et al., 2008; Oliveira et al., 2010). Both line $85 \mathrm{AD}$ mice and control mice have a high level of 5-LOX, which is reduced by $>40 \%$ following a diet containing CNB-001. The ability of 5-LOX to mediate eIF $2 \alpha$ phosphorylation and the UPR in the context of $A \beta$ clearance may explain the multiple observations linking arachidonic acid metabolism to $\mathrm{AD}$ pathology.

The phosphorylation of eIF $2 \alpha$ frequently leads to the induction of ATF4. CNB-001 increases ATF4 expression both in vivo and in $\mathrm{AD}$ mice, and is neuroprotective. Furthermore, ATF4 induction via the UPR requires PERK phosphorylation, and knockdown of PERK enhances extracellular $A \beta$ neurotoxicity in neurons (Lee do et al., 2010) and also decreases multiple aspects of cognitive function (Trinh et al., 2012). We show here that the induction of ATF4 by CNB-001 requires PERK. Importantly, MC65 cells making A $\beta$ respond differently to CNB-001 in terms of the UPR than uninduced cells (Fig. 4). This observation strongly suggests that the molecular responses to the inhibition of 5 -LOX are directly related to the level of cellular stress caused by intracellular $\mathrm{A} \beta$.

The response of transgenic $\mathrm{AD}$ mice to $\mathrm{CNB}-001$ confirms several aspects of the cell culture data. These include a reduction 


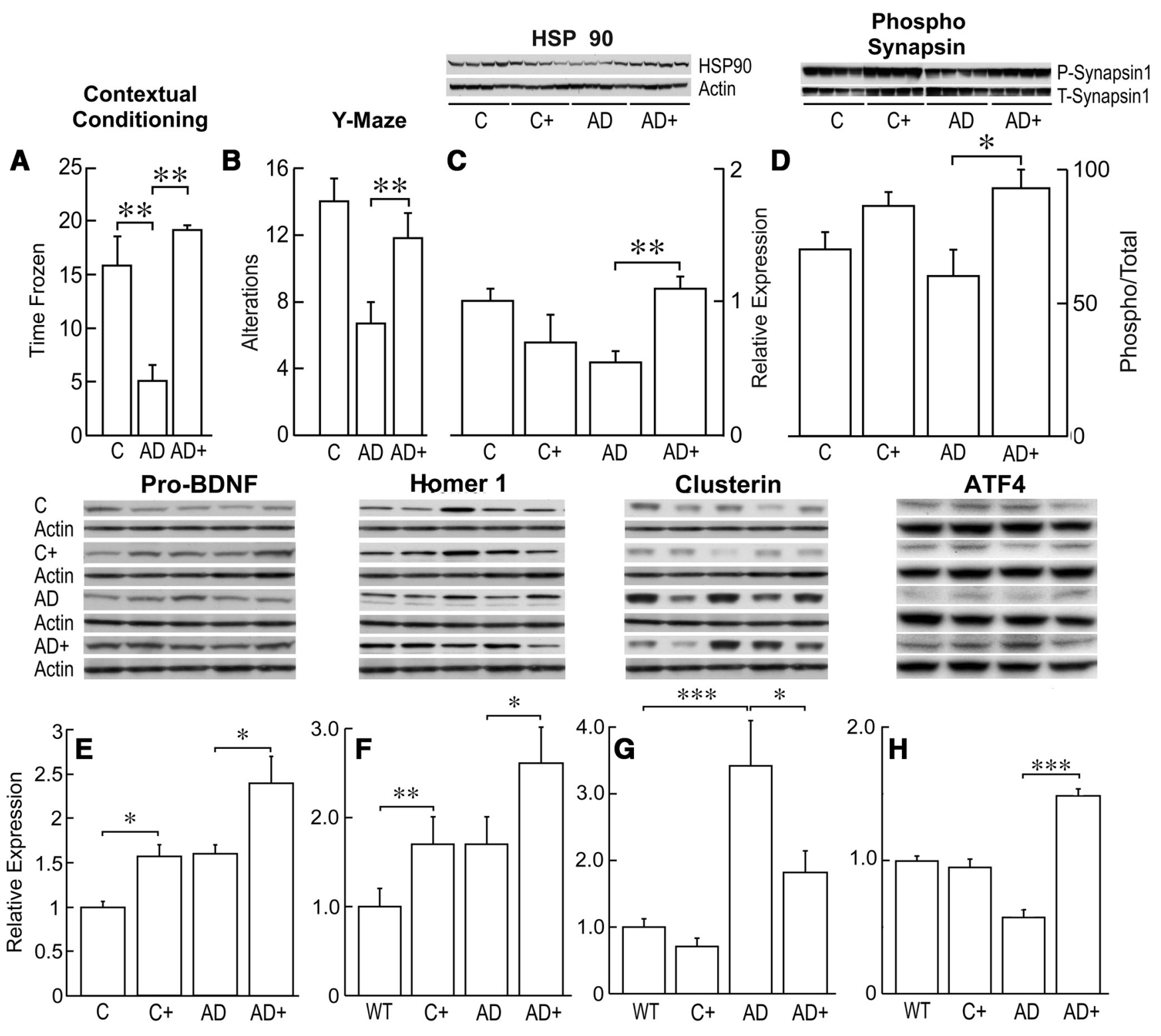

Figure 11. CNB-001 reverses cognitive deficits and maintains synaptic proteins in an AD mouse model. $A$, CNB-001 blocks A $\beta$ disruption of contextual memory. Cannula were bilaterally implanted in the dorsal hippocampi of mice, and CNB- $001500 \mathrm{mg} / \mathrm{kg}$ or gavage solution alone was orally administered $30 \mathrm{~min}$ before training and $15 \mathrm{~min}$ before training; $A \beta_{1-42}(500 \mathrm{~nm}$ ) was bilaterally injected. Animals were subjected to the standard fear conditioning training paradigm and were assayed $24 \mathrm{~h}$ later. The data are shown as the time frozen (in seconds) with gavage alone, $\mathrm{A} \beta_{1-42}$ alone, or $A \beta_{1-42}$ plus CNB-001 (performed by Psychogenics). B, 9-month-old hAPP/Swe/PS1 $\Delta$ E9 mice were fed 500 ppm CNB-001 ( $\sim 25 \mathrm{mg} / \mathrm{kg} / \mathrm{d}$ ) from $3 \mathrm{months}$ of age and were assayed for memory in the Y-maze. A lower number of alterations indicates reduced memory of previous explorations. The hippocampi from the mice in $\boldsymbol{B}$ were isolated and assayed for HSP90 in the $100,000 \times g$ RIPA-insoluble fraction (there is no change in the soluble fraction; $\boldsymbol{C}$; ; phosphosynapsin-1 (RIPA soluble; $\boldsymbol{D}$ ); Pro-BDNF (soluble; $\boldsymbol{E}$ ); Homer 1 (soluble; $\boldsymbol{F}$ ); clusterin (soluble; $\boldsymbol{G}$ ); ATF4 ( $\boldsymbol{H}$ ). Statistics are done by one-way ANOVA with 8-10 animals per group, 4 or 5 animals per group are shown. ${ }^{*} p<0.05 ;{ }^{* *} p<0.01 ;{ }^{* * *} p<0.001$.

of aggregated protein, the higher expression of ATF4 and HSP90, and the reduced expression of 5-LOX. In addition, the phosphorylation of eIF $2 \alpha$ is greatly enhanced both in vivo and in vitro. We have shown that the phosphorylation of the UPR component eIF2 $\alpha$ is very neuroprotective against multiple aspects of oxidative stress (Tan et al., 2001a). HSP90 is a marker for some aspects of the UPR, and there is a decrease in HSP90 in AD mice relative to control AD mice that is restored to control levels by CNB-001. Chaperones such as HSP90 bind amyloidogenic proteins and may affect their aggregation process. These chaperones not only colocalize with the pathological lesions of $\mathrm{AD}$, but may also be involved in the clearance of $\mathrm{A} \beta$ from the brain via phagocytosis or active transport across the blood-brain barrier (Wilhelmus et al., 2007).
BDNF is a neurotrophic growth factor that is required for learning and memory as well as the overall maintenance and survival of CNS neurons, and several observations link BDNF to the UPR. Pro-BDNF is reduced in AD brain (Michalski and Fahnestock, 2003), and CNB-001 increases BDNF mRNA in rat models of traumatic brain injury (Wu et al., 2011). Here we show that pro-BDNF was increased by CNB-001 in control mice and to a similar extent in $\mathrm{AD}$ mice. CNB-001 also increased the downstream target of BDNF, Homer 1, in control and AD mice. CNB001 causes the phosphorylation of synapsin-1, a synaptic spine protein whose phosphorylation is mediated indirectly by BDNF. The activation of the PERK/eIF $2 \alpha$ arm of the UPR can lead to the elevation of death-promoting protein CHOP. BDNF is known to block CHOP induction (Chen et al., 2007), but activate some com- 
A Hippocampal elF2 $\alpha$
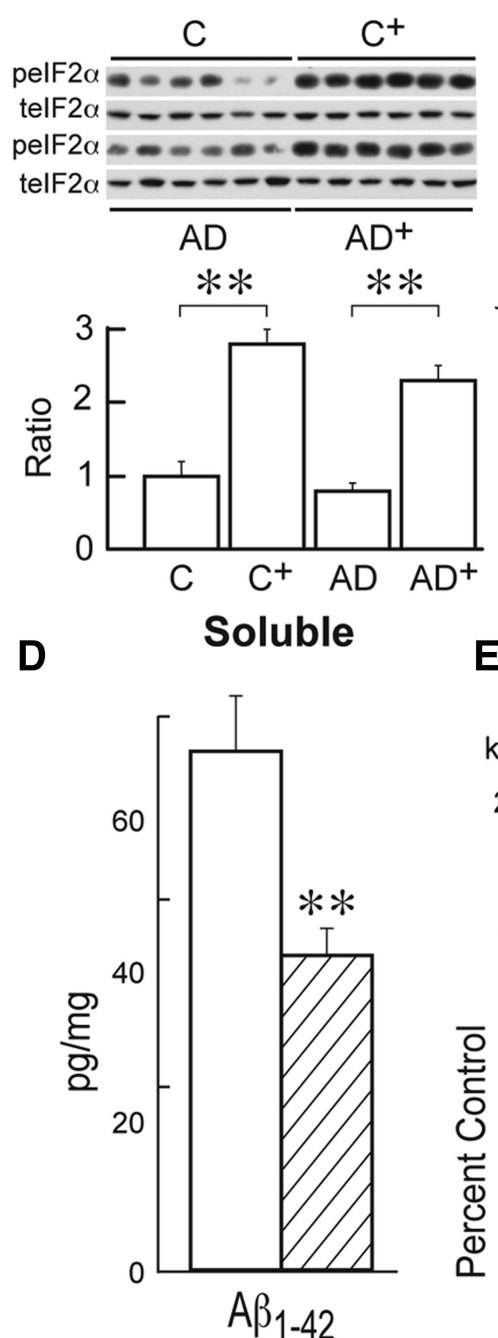

B

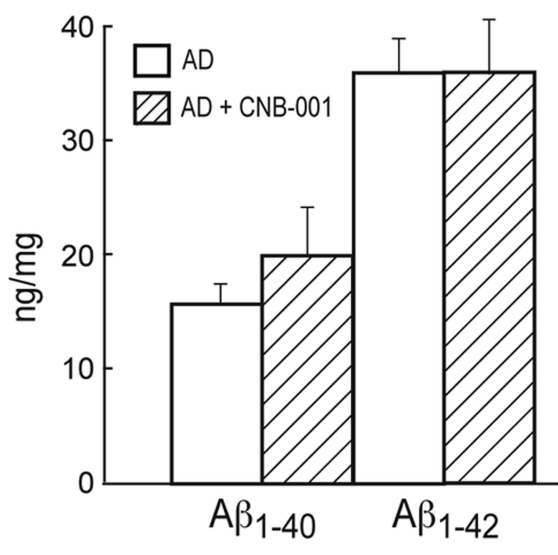

Anti-Ub

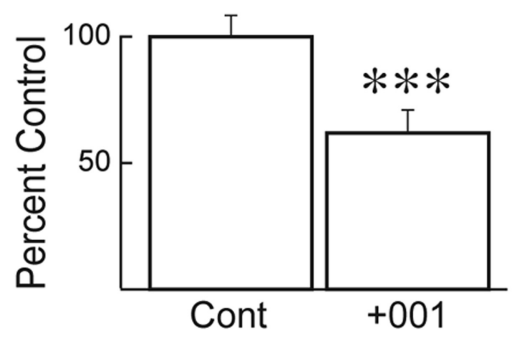

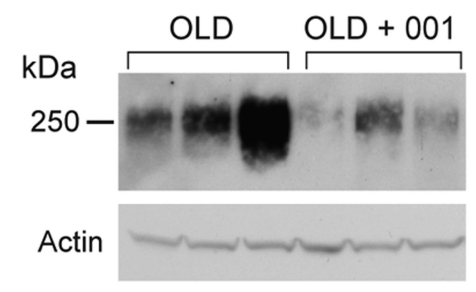

E

Cont

\section{Soluble}

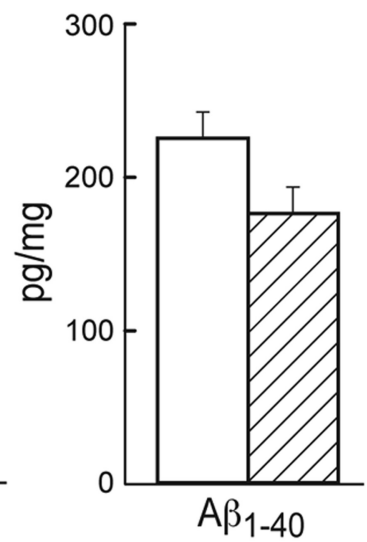

\section{$\mathbf{F}$}

5-LOX Hippocampus
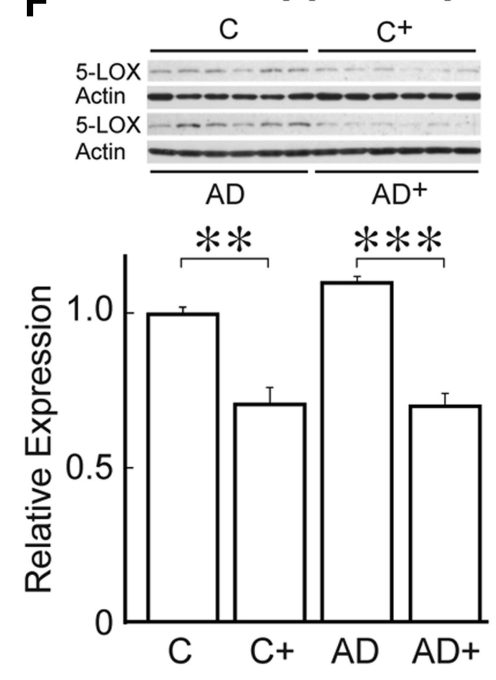

Figure 12. CNB-001 induces hippocampal elF $2 \alpha$ phosphorylation, and reduces soluble $A \beta_{1-42}$ and ubiquitinated proteins in AD mice. $A$, Hippocampal lysates from $A D$ mice fed 500 ppm CNB-001 were immunoblotted with anti-phospho and total elF2 $\alpha$. C, Control; $A, A D ; C+$, control plus CNB-001; $A+, A D+C N B-001 .{ }^{*} p<0.05 ; *^{* *} p<0.01 ;{ }^{* * *} p<0.001 . B-D$, $A \beta_{1-40}$ and $A \beta_{1-42}$ levels were measured by ELISA in the RIPA-soluble and the RIPA-insoluble 100,000 $\times g$ pellet of hippocampal lysates of 10-month-old mice fed CNB-001 or control diet for 7 months. $\boldsymbol{B}$, Insoluble pellet. $\boldsymbol{C}$, RIPA-soluble supernatant, $A \beta_{1-40}$. $\boldsymbol{D}$, RIPA-soluble fraction, $A \beta_{1-42} \cdot{ }^{* *} p<0.01$. $n=10$ per group. $\boldsymbol{E}$, RIPA-insoluble protein was immunoblotted with anti-ubiquitin. A reduction in ubiquitinated particulate protein was seen in 9-month-old mice that had been fed CNB-001 at 500 ppm in chow for the previous 6 months. $\boldsymbol{F}, 5$-LOX expression was monitored in the hippocampus of AD transgenic mice fed CNB-001 for 6 months (see Fig. 11). ${ }^{* *} p<0.01 ;{ }^{* * *} p<0.001$.

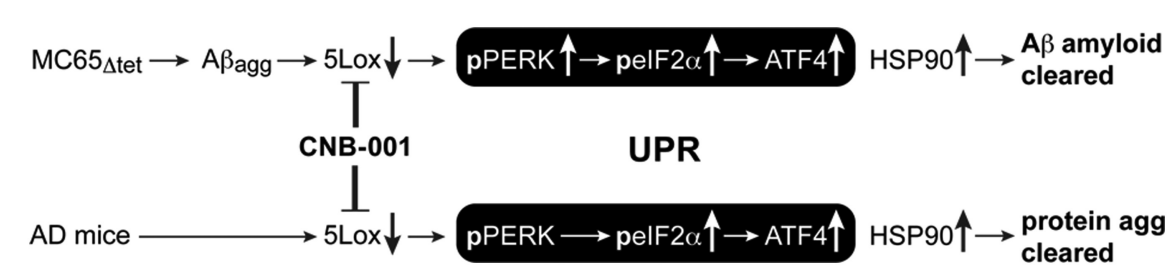

Figure 13. Schematic representation of the effect of CNB-001 on the metabolism of aggregated proteins both in vitro and in vivo.

ponents of the UPR (Hayashi et al., 2007). CNB-001 activates the $\mathrm{BDNF}$ signaling pathway in the absence of the $\mathrm{BDNF}$ receptor (Liu et al., 2008) as well as stimulates BDNF and pro-BDNF accumulation in the brain (Wu et al., 2011; Fig. 12E). Therefore, the stimulation of the BDNF signaling pathway may explain why CNB-001 strongly induces the PERK/eIF $2 \alpha$ arm of the UPR but not CHOP.

Finally, clusterin, also known as apolipoprotein J, is greatly increased in AD brain as well as with aging (Wu et al., 2012).
Clusterin expression was significantly elevated in $\mathrm{AD}$ mice and reduced to control levels by CNB-001, another indication that CNB-001 is normalizing brain physiology. Together, these data show that CNB-001 enhances the expression of pathways involved in neuroprotection, $\mathrm{A} \beta$ clearance, as well as learning and memory.

In conclusion, the intracellular accumulation of toxic polymers is prevented by the 5-LOX inhibitor CNB-001. In cultured MC65 cells, CNB-001 not only protects from cell death but also induces the degradation of $A \beta$ aggregates as well as their secretion to the extracellular matrix. The accumulation of aggregated A $\beta$ in MC65 cells leads to elevated 5-LOX. 5-LOX metabolites lower components of the eIF $2 \alpha$ arm of the UPR, resulting in the accumulation of $\mathrm{A} \beta$ aggregates and cell death. The inhibition of 5-LOX by CNB-001 leads to a reduction of 5-LOX protein 
and the activation of the PERK/eIF2 $\alpha /$ ATF4 arm of the UPR, resulting in degradation of $A \beta$ aggregates through either the proteasome or lysosome and cell survival. In mice, CNB-001 significantly reduces 5 -LOX, and elevates eIF $2 \alpha$ phosphorylation and ATF4 expression, resulting in a reduction in overall insoluble aggregated protein in the hippocampus. This information is shown schematically in Figure 13. Finally, CNB-001 reduces the accumulation of soluble $\mathrm{A} \beta_{1-42}$ and improves memory in animal models of AD. These data show that the pharmacological manipulation of 5-LOX and the PERK/eIF2 $\alpha /$ ATF4 arm of the UPR may be useful for the treatment of $\mathrm{AD}$ and other neurodegenerative diseases caused by proteotoxicity.

\section{References}

Billings LM, Oddo S, Green KN, McGaugh JL, LaFerla FM (2005) Intraneuronal Abeta causes the onset of early Alzheimer's disease-related cognitive deficits in transgenic mice. Neuron 45:675-688. CrossRef Medline

Chakrabortee S, Liu Y, Zhang L, Matthews HR, Zhang H, Pan N, Cheng CR, Guan SH, Guo DA, Huang Z, Zheng Y, Tunnacliffe A (2012) Macromolecular and small molecule modulation of intracellular Abeta42 aggregation and associated toxicity. Biochem J 442:507-515. CrossRef Medline

Chen G, Fan Z, Wang X, Ma C, Bower KA, Shi X, Ke ZJ, Luo J (2007) Brain-derived neurotrophic factor suppresses tunicamycin-induced upregulation of CHOP in neurons. J Neurosci Res 85:1674-1684. CrossRef Medline

Chen Q, Prior M, Dargusch R, Roberts A, Riek R, Eichmann C, Chiruta C, Akaishi T, Abe K, Maher P, Schubert D (2011) A novel neurotrophic drug for cognitive enhancement and Alzheimer's disease. PLoS One 6:e27865. CrossRef Medline

Chui DH, Tanahashi H, Ozawa K, Ikeda S, Checler F, Ueda O, Suzuki H, Araki W, Inoue H, Shirotani K, Takahashi K, Gallyas F, Tabira T (1999) Transgenic mice with Alzheimer presenilin 1 mutations show accelerated neurodegeneration without amyloid plaque formation. Nat Med 5:560-564. CrossRef Medline

Evans CG, Wisén S, Gestwicki JE (2006) Heat shock proteins 70 and 90 inhibit early stages of amyloid beta-(1-42) aggregation in vitro. J Biol Chem 281:33182-33191. CrossRef Medline

Firuzi O, Zhuo J, Chinnici CM, Wisniewski T, Praticò D (2008) 5 -Lipoxygenase gene disruption reduces amyloid-beta pathology in a mouse model of Alzheimer's disease. FASEB J 22:1169-1178. CrossRef Medline

Goldsbury C, Whiteman IT, Jeong EV, Lim YA (2008) Oxidative stress increases levels of endogenous amyloid-beta peptides secreted from primary chick brain neurons. Aging Cell 7:771-775. CrossRef Medline

Hayashi A, Kasahara T, Iwamoto K, Ishiwata M, Kametani M, Kakiuchi C, Furuichi T, Kato T (2007) The role of brain-derived neurotrophic factor (BDNF)-induced XBP1 splicing during brain development. J Biol Chem 282:34525-34534. CrossRef Medline

Himeno E, Ohyagi Y, Ma L, Nakamura N, Miyoshi K, Sakae N, Motomura K, Soejima N, Yamasaki R, Hashimoto T, Tabira T, LaFerla FM, Kira J (2011) Apomorphine treatment in Alzheimer mice promoting amyloidbeta degradation. Ann Neurol 69:248-256. CrossRef Medline

Hong HS, Maezawa I, Yao N, Xu B, Diaz-Avalos R, Rana S, Hua DH, Cheng RH, Lam KS, Jin LW (2007) Combining the rapid MTT formazan exocytosis assay and the MC65 protection assay led to the discovery of carbazole analogs as small molecule inhibitors of Abeta oligomer-induced cytotoxicity. Brain Res 1130:223-234. CrossRef Medline

Ishige K, Chen Q, Sagara Y, Schubert D (2001) The activation of dopamine D4 receptors inhibits oxidative stress-induced nerve cell death. J Neurosci 21:6069-6076. Medline

Jankowsky JL, Melnikova T, Fadale DJ, Xu GM, Slunt HH, Gonzales V, Younkin LH, Younkin SG, Borchelt DR, Savonenko AV (2005) Environmental enrichment mitigates cognitive deficits in a mouse model of Alzheimer's disease. J Neurosci 25:5217-5224. CrossRef Medline

Jankowsky JL, Younkin LH, Gonzales V, Fadale DJ, Slunt HH, Lester HA, Younkin SG, Borchelt DR (2007) Rodent A beta modulates the solubility and distribution of amyloid deposits in transgenic mice. J Biol Chem 282:22707-22720. CrossRef Medline

Kaneko M, Koike H, Saito R, Kitamura Y, Okuma Y, Nomura Y (2010) Loss of HRD1-mediated protein degradation causes amyloid precursor pro- tein accumulation and amyloid- $\beta$ generation. J Neurosci 30:3924-3932. CrossRef Medline

Kögel D, Concannon CG, Müller T, König H, Bonner C, Poeschel S, Chang S, Egensperger R, Prehn JH (2012) The APP intracellular domain (AICD) potentiates ER stress-induced apoptosis. Neurobiol Aging 33:2200-2209. CrossRef Medline

Komatsu M, Waguri S, Chiba T, Murata S, Iwata J, Tanida I, Ueno T, Koike M, Uchiyama Y, Kominami E, Tanaka K (2006) Loss of autophagy in the central nervous system causes neurodegeneration in mice. Nature 441: 880-884. CrossRef Medline

Krafft GA, Klein WL (2010) ADDLs and the signaling web that leads to Alzheimer's disease. Neuropharmacology 59:230-242. CrossRef Medline

Kunte MM, Choudhury S, Manheim JF, Shinde VM, Miura M, Chiodo VA, Hauswirth WW, Gorbatyuk OS, Gorbatyuk MS (2012) ER stress is involved in T17M rhodopsin-induced retinal degeneration. Invest Ophthalmol Vis Sci 53:3792-3800. CrossRef Medline

LaFerla FM, Green KN, Oddo S (2007) Intracellular amyloid-beta in Alzheimer's disease. Nat Rev Neurosci 8:499-509. CrossRef Medline

Lee do Y, Lee KS, Lee HJ, Kim do H, Noh YH, Yu K, Jung HY, Lee SH, Lee JY, Youn YC, Jeong Y, Kim DK, Lee WB, Kim SS (2010) Activation of PERK signaling attenuates Abeta-mediated ER stress. PLoS One 5:e10489. CrossRef Medline

Lee JH, Won SM, Suh J, Son SJ, Moon GJ, Park UJ, Gwag BJ (2010) Induction of the unfolded protein response and cell death pathway in Alzheimer's disease, but not in aged Tg2576 mice. Exp Mol Med 42:386-394. CrossRef Medline

Lewerenz J, Maher P (2009) Basal levels of eIF2alpha phosphorylation determine cellular antioxidant status by regulating ATF4 and xCT expression. J Biol Chem 284:1106-1115. CrossRef Medline

Liu Y, Dargusch R, Maher P, Schubert D (2008) A broadly neuroprotective derivative of curcumin. J Neurochem 105:1336-1345. CrossRef Medline

Luo M, Jones SM, Flamand N, Aronoff DM, Peters-Golden M, Brock TG (2005) Phosphorylation by protein kinase a inhibits nuclear import of 5-lipoxygenase. J Biol Chem 280:40609-40616. CrossRef Medline

Maezawa I, Jin LW, Woltjer RL, Maeda N, Martin GM, Montine TJ, Montine KS (2004) Apolipoprotein E isoforms and apolipoprotein AI protect from amyloid precursor protein carboxy terminal fragment-associated cytotoxicity. J Neurochem 91:1312-1321. CrossRef Medline

Maezawa I, Hong HS, Wu HC, Battina SK, Rana S, Iwamoto T, Radke GA, Pettersson E, Martin GM, Hua DH, Jin LW (2006) A novel tricyclic pyrone compound ameliorates cell death associated with intracellular amyloid-beta oligomeric complexes. J Neurochem 98:57-67. CrossRef Medline

Maher P, Akaishi T, Schubert D, Abe K (2010) A pyrazole derivative of curcumin enhances memory. Neurobiol Aging 31:706-709. CrossRef Medline

Michalski B, Fahnestock M (2003) Pro-brain-derived neurotrophic factor is decreased in parietal cortex in Alzheimer's disease. Brain Res Mol Brain Res 111:148-154. CrossRef Medline

Nixon RA (2007) Autophagy, amyloidogenesis and Alzheimer disease. J Cell Sci 120:4081-4091. CrossRef Medline

Oakley H, Cole SL, Logan S, Maus E, Shao P, Craft J, Guillozet-Bongaarts A, Ohno M, Disterhoft J, Van Eldik L, Berry R, Vassar R (2006) Intraneuronal $\beta$-amyloid aggregates, neurodegeneration, and neuron loss in transgenic mice with five familial Alzheimer's disease mutations: potential factors in amyloid plaque formation. J Neurosci 26:10129-10140. CrossRef Medline

Oddo S, Caccamo A, Tran L, Lambert MP, Glabe CG, Klein WL, LaFerla FM (2006) Temporal profile of amyloid- $\beta(\mathrm{A} \beta$ ) oligomerization in an in vivo model of Alzheimer disease. A link between $\mathrm{A} \beta$ and tau pathology. J Biol Chem 281:1599-1604. CrossRef Medline

Oliveira TG, Chan RB, Tian H, Laredo M, Shui G, Staniszewski A, Zhang H, Wang L, Kim TW, Duff KE, Wenk MR, Arancio O, Di Paolo G (2010) Phospholipase D2 ablation ameliorates Alzheimer's disease-linked synaptic dysfunction and cognitive deficits. J Neurosci 30:16419-16428. CrossRef Medline

Qu T, Uz T, Manev H (2000) Inflammatory 5-LOX mRNA and protein are increased in brain of aging rats. Neurobiol Aging 21:647-652. CrossRef Medline

Sanchez-Mejia RO, Newman JW, Toh S, Yu GQ, Zhou Y, Halabisky B, Cissé M, Scearce-Levie K, Cheng IH, Gan L, Palop JJ, Bonventre JV, Mucke L (2008) Phospholipase A2 reduction ameliorates cognitive deficits in a 
mouse model of Alzheimer's disease. Nat Neurosci 11:1311-1318. CrossRef Medline

Sato M, Suzuki K, Nakanishi S (2001) NMDA receptor stimulation and brain-derived neurotrophic factor upregulate homer la mRNA via the mitogen-activated protein kinase cascade in cultured cerebellar granule cells. J Neurosci 21:3797-3805. Medline

Schubert D (1977) The substrate attached material synthesized by clonal cell lines of nerve, glia, and muscle. Brain Res 132:337-346. CrossRef Medline

Schubert D, Maher P (2012) An alternative approach to drug discovery for Alzheimer's disease dementia. Future Med Chem 4:1681-1688. CrossRef Medline

Simonsen A, Cumming RC, Brech A, Isakson P, Schubert DR, Finley KD (2008) Promoting basal levels of autophagy in the nervous system enhances longevity and oxidant resistance in adult Drosophila. Autophagy 4:176-184. Medline

Song X, Luo Y (2010) The regulatory mechanism of Hsp90alpha secretion from endothelial cells and its role in angiogenesis during wound healing. Biochem Biophys Res Commun 398:111-117. CrossRef Medline

Sopher BL, Fukuchi K, Smith AC, Leppig KA, Furlong CE, Martin GM (1994) Cytotoxicity mediated by conditional expression of a carboxylterminal derivative of the beta-amyloid precursor protein. Brain Res Mol Brain Res 26:207-217. CrossRef Medline

Steele JW, Gandy S (2011) Apomorphine and Alzheimer Abeta: roles for regulated alpha cleavage, autophagy, and antioxidation? Ann Neurol 69: 221-225. CrossRef Medline

Tampellini D, Capetillo-Zarate E, Dumont M, Huang Z, Yu F, Lin MT, Gouras GK (2010) Effects of synaptic modulation on $\beta$-amyloid, synaptophysin, and memory performance in Alzheimer's disease transgenic mice. J Neurosci 30:14299-14304. CrossRef Medline

Tampellini D, Rahman N, Lin MT, Capetillo-Zarate E, Gouras GK (2011) Impaired $\beta$-amyloid secretion in Alzheimer's disease pathogenesis. J Neurosci 31:15384-15390. CrossRef Medline
Tan S, Somia N, Maher P, Schubert D (2001a) Regulation of antioxidant metabolism by translation initiation factor-2 alpha. J Cell Biol 152: 997-1006. CrossRef Medline

Tan S, Schubert D, Maher P (2001b) Oxytosis: a novel form of programmed cell death. Curr Top Med Chem 1:497-506. CrossRef Medline

Trinh MA, Kaphzan H, Wek RC, Pierre P, Cavener DR, Klann E (2012) Brain-specific disruption of the eIF2alpha kinase PERK decreases ATF4 expression and impairs behavioral flexibility. Cell reports 1:676-688. CrossRef Medline

Wilhelmus MM, de Waal RM, Verbeek MM (2007) Heat shock proteins and amateur chaperones in amyloid-Beta accumulation and clearance in Alzheimer's disease. Mol Neurobiol 35:203-216. CrossRef Medline

Wirths O, Multhaup G, Czech C, Blanchard V, Moussaoui S, Tremp G, Pradier L, Beyreuther K, Bayer TA (2001) Intraneuronal Abeta accumulation precedes plaque formation in beta-amyloid precursor protein and presenilin-1 double-transgenic mice. Neurosci Lett 306:116-120. CrossRef Medline

Wu A, Ying Z, Schubert D, Gomez-Pinilla F (2011) Brain and spinal cord interaction: a dietary curcumin derivative counteracts locomotor and cognitive deficits after brain trauma. Neurorehabil Neural Repair 25: 332-342. CrossRef Medline

Wu Z-C, Yu J-T, Li Y, Tan L (2012) Clusterin in Alzheimer's Disease. In: Advances in clinical chemistry, Vol 56 (Makowski GS, ed.), pp 155-173. Salt Lake City, UT: Academic.

Zhang W, Hao J, Liu R, Zhang Z, Lei G, Su C, Miao J, Li Z (2011) Soluble Abeta levels correlate with cognitive deficits in the 12-month-old APPswe/PS1dE9 mouse model of Alzheimer's disease. Behav Brain Res 222:342-350. CrossRef Medline

Zhu K, Dunner K Jr, McConkey DJ (2010) Proteasome inhibitors activate autophagy as a cytoprotective response in human prostate cancer cells. Oncogene 29:451-462. CrossRef Medline 